\title{
VERTICAL RESTRAINTS UNDER EU COMPETITION LAW: CONCEPTUAL FOUNDATIONS AND PRACTICAL FRAMEWORK
}

\author{
Nicolas Petit ${ }^{*}$ and David Henry ${ }^{* *}$
}

\section{INTRODUCTION}

Each manufacturer seeking to convey goods or services to customers faces a basic, standard choice. ${ }^{1}$ It may either distribute them directly, through downstream vertical integration (integrated distribution), or it may entrust this task to specialised agents via the conclusion of a vertical agreement (independent distribution). ${ }^{2}$

This paper focuses on independent distribution and how it is treated pursuant to the provisions of European Union ("EU”) competition law. Since the 1960s and the Consten and Grundig case, ${ }^{3}$ it is acknowledged that vertical agreements can entail restrictions of competition - generally called "vertical restraints" - which merit

* Professor, University of Liege School of Law; Director, Brussels School of Competition.

** Practising barrister admitted to the Bar of England and Wales; Associate, Howrey LLP, Brussels. The authors are grateful to Charlotte Lousberg and Elise Provost for their helpful comments on previous drafts of this paper.

1 See R. Coase, "The Nature of the Firm" (1937) 4 Economica 386; O. Williamson, Market and Hierarchies: Analysis and Antitrust Implications, New York, Free Press, 1975. Economists sometimes speak of "hierarchy" (the firm) and "delegation" (the market) strategies. The choice of one or other method of distribution obviously varies according to the relevant sector, timing, and a company's individual preferences. For example, with regard to the distribution of personal computers, though traditionally carried out using the independent distribution method, the past ten years have shown a growing trend towards integration. Clearly, the manufacturer may still decide to combine these two forms of distribution ("dual distribution"). Economic research and in particular, the "theory of the firm" has identified the main determinants of such choice. According to R. Coase, recourse to independent distribution leads to transaction costs (or governance costs) in terms of research, negotiation and performance problems. In contrast, under the integrated model, firms avoid (some) transaction costs as there exists a relationship of "authority". However, their production costs increase in such an integrated model. There is, therefore, a trade-off between transaction costs and production costs.

2 An agreement governing the relationship between the supplier and a distributor is generally termed a "vertical agreement" because it involves the cooperation of non-competing undertakings active at different stages of the value chain. Distribution agreements between operators at the same level of production process are called horizontal agreements. The integrated distribution model also raises competition law issues, which are generally assessed under the merger control or abuse of dominance rules.

3 See Judgment of the Court of 13 July 1966, Joined cases 56 and 58-64, Etablissements Consten SARL and Grundig-Verkaufs GmbH v. Commission, [1966] ECR 299. 
competition law scrutiny. ${ }^{4}$ While the early case law and regulations adopted in the field focused primarily on restrictions of intra-brand competition, ${ }^{5}$ and condemned many contractual clauses per se, regardless of their actual effects, ${ }^{6}$ a more liberal, and economic approach was introduced with the promulgation of Regulation 2790/1999. ${ }^{7}$ For a long time, legal and economic studies had indeed cast light on the fact that vertical agreements had virtually as many pro-competitive effects as anti-competitive ones. ${ }^{8}$ Following one of the most vociferous debates in the history of EU competition law, ${ }^{9}$ a consensus emerged regarding the fact that competition authorities ought to focus on cases raising real competition concerns i.e. those where inter-brand competition (between competing goods or services) is actually hampered, so that any further restriction of intra-brand competition becomes problematic. Vertical restraints on tight oligopolistic markets were a case in point. On those markets, which are prone to collusive outcomes, competition between suppliers tends to be weak. ${ }^{10}$

In response to this, the Commission initiated studies in 1997 with a view to reforming the law of vertical agreements. ${ }^{11}$ This process culminated in 1999 with the adoption of block exemption Regulation 2790/1999. The new legal framework, which represented

4 A vertical agreement is defined in Article 1(1)(a) of Regulation 330/2010 as covering: "an agreement or concerted practice entered into between two or more undertakings each of which operates, for the purposes of the agreement or the concerted practice, at a different level of the production or distribution chain, and relating to the conditions under which the parties may purchase, sell or resell certain goods or services". According to Article (1)(1)(b) of the Regulation a "vertical restraint" means a restriction of competition in a vertical agreement falling within the scope of Article 101(1) TFEU - see Commission Regulation 330/2010 of 20 April 2010 on the application of Article 101(3) of the Treaty on the Functioning of the European Union to categories of vertical agreements and concerted practices (2010) OJ L 102 ("the Regulation").

5 A large number of contractual clauses that hampered competition between distributors of the same good or service (territorial exclusivity etc) were thus prohibited.

6 During this early period, and for a considerable length of time thereafter, the analysis of vertical agreements was characterised by a distinct absence of a real and substantive nexus between law and economic analysis. Agreements between parties that did not enjoy market power could thus be prohibited by the Commission without any meaningful economic analysis being performed to substantiate such findings.

7 See in this context S. Bishop, "Unfinished Business: The New Approach to Assessing Vertical Restraints", Intereconomics, January/February 2002.

8 See, on this point, J. Tirole, The Theory of Industrial Organization, The MIT Press, Cambridge, Massachusetts, 1988, chapter IV.

9 See B. E. Hawk, "System Failure: Vertical Restraints and EC Competition Law", (1995) 35 CMLR 973.

10 Network industries, in which there are natural monopolies or oligopolies, are typically an area where inter-brand competition is limited.

11 See F. Wijckmans, F. Tuytschaever and A. Vanderelst, Vertical Agreements in EC Competition Law, first edition, Oxford University Press, Oxford 2006, paras. 1.51 et seq. 
a radical departure from the previous approach, ${ }^{12}$ rested on a basic economic premise: the ability of a vertical agreement to produce anti-competitive effects hinges predominantly on the market power of the parties to the agreement (especially the supplier's market share, which reveals the degree of inter-brand competition). In turn, the system instituted a safe-harbour mechanism whereby any agreement between parties holding less than a predetermined "market share" (and which observed a (shorter) list of black clauses and conditions) could be presumed to benefit from an exemption under what is now Article 101(3) TFEU. ${ }^{13}$ Above the relevant market share threshold, a full assessment, known as an "individual assessment", needed to be carried out in the light of the principles mentioned in a set of complementary Guidelines. $^{14}$ In addition, the new legal framework also governed Internet distribution, which was not covered previously. ${ }^{15}$

With the expiry of Regulation 2790/1999 on 31 May 2010, but also with the growth of massive retailers throughout Europe and the rise of Internet distribution (B2B or B2C), the Commission initiated a review process in July 2009. These factors therefore gave impetus to the recent reform process culminating in the adoption of Regulation $330 / 2010$ and of a new set of Guidelines. ${ }^{16}$

Against this background the purpose of this study is provide an overview of the new legal regime applicable to vertical agreements. To this end, it is divided in five sections. Following this introduction, section II sets out the different types of vertical restraint and the theories of competitive harm ascribed to them. Section III offers a step-by-step overview of the method that should be followed by agencies, firms and their counsels with a view to self assessing - in the post notification era - vertical

12 And more generally, marks the beginning of the "effects-based" approach in EU competition enforcement.

13 From a legal practitioner's point of view it may have been somewhat disappointing to see that the convenient lists of black, grey and white clauses applicable under the former regime had disappeared. In addition, notwithstanding the simplified regime resulting from the disappearance of a multitude of texts applicable to distribution agreements, legal practitioners viewed the reform as somewhat disconcerting as the new texts borrowed heavily from the nebulous jargon of industrial economics - witness the terms now used such as "market share", "foreclosure effects", "economies of scale", etc.

14 See Commission notice - Guidelines on Vertical Restraints (2010) OJ C 130/1 ("the Guidelines"), para. 96.

15 With the Internet's rapid development and easy accessibility it became imperative to review the system of control of independent distribution agreements in order to align it with commercial realities.

16 See supra notes 4 and 14. 
agreements under EU competition law. Section IV deals with the issue of online distribution, which sparked intense controversy during the stakeholder consultation process. Finally, a brief conclusion is provided in section $\mathrm{V}$.

\section{TYPES OF VERTICAL RESTRAINT}

\section{THE ISSUE}

With the paradigmatic shift towards an economic approach in 1999, and its confirmation in the recently adopted texts, EU law has migrated from a "form-based approach" to a so-called "effects-based approach". Pursuant to Regulation 330/2010 and the Guidelines, the nub of the matter is to determine whether a vertical agreement (or part of it), has actual or potential anti-competitive effects that are not outweighed by pro-competitive effects (or objective justifications).

Within the new regulatory framework, six groups of vertical restraint, with distinct possible anticompetitive effects, can be distinguished. ${ }^{17}$ In line with the way economists work, the Guidelines ascribe one or more theories of competitive harm to each of these types of restriction and identify their possible countervailing objective justifications as well as pro-competitive effects.

\section{THE EXCLUSIVE CONTRACTUAL RELATIONSHIP GROUP}

\subsection{Notion of exclusive contractual relationships}

In an exclusive contractual relationship, a party to a vertical agreement relinquishes its freedom to contract with a third party. Its most drastic variant can be found in "single branding" arrangements, which limit a buyer's ability to buy, resell or use as inputs competing goods or services. ${ }^{18}$ Less extreme declinations of exclusive

17 The Guidelines also devote some space to other types of vertical restraints, such as franchising at paras. 189-191 and tying at paras. 214-222. These issues will not be dealt with in the present paper.

18 The idea here is to prevent the buyer from supplying itself with products of another brand. See the Guidelines, supra note 14, para. 129. Exclusive purchasing leads to a similar result but, as will be seen later, it responds to a significantly distinct definition. This explains why the Commission mentions exclusive purchasing in the same breath as vertical restrictions belonging to the 
contractual relationships include quantity forcing, ${ }^{19}$ conditional rebate schemes, twopart tariffs (fixed fee plus a price per unit), tying arrangements (where the sale of one product is conditional upon the purchase of another), ${ }^{20}$ or any other clauses (e.g. "English clauses") ${ }^{21}$ or penalties which render more rigid the supplier/buyer relationship by encouraging the buyer to concentrate its purchases of goods or services with its customary supplier. ${ }^{22}$

The Van den Bergh Foods case is a good illustration of an exclusive contractual relationship. ${ }^{23}$ A supplier of "impulse" ice cream had made freezers available to its Irish distributors for free. In return, the distributors were contractually required to refrain from storing other brands of ice cream in those freezers.

An exclusive contractual relationship may also appear in the context of exclusive supply arrangements. Here, the supplier is obliged (or incentivized) to sell the contractual goods or services only (or mainly) to one buyer, in general or for a particular use. $^{24}$

\subsection{Theories of competitive harm}

Drawing on economic theory, the Guidelines ascribe three theories of competitive harm to exclusive contractual relations, namely foreclosure, collusion, and reduced consumer choice. First, exclusive contracts may foreclose competitors' access to outlets (in the case of single branding or long-term contracts, for example) or inputs (in the case of exclusive supply, for example). In a market subject to widespread single branding arrangements, a new supplier willing to enter the market has no other

exclusive distribution group. The concept of a non-compete obligation would appear to cover both single branding and exclusive purchasing.

19 The Commission still treats purchase quotas with a greater degree of leniency than exclusivity commitments. See for example, the Guidelines, supra note 14, para. 154

20 See the Guidelines, supra note 14 , para 214-222

21 See the Guidelines, supra note 14, para. 129.

22 Contracts with penalty clauses may create a risk of foreclosure and deter entry.

23 See Judgment of the General Court, Case T-65/98, Van den Bergh Foods v. Commission, [1998] ECR II-2641.

24 See the Guidelines, supra note 14, para. 192. In the Guidelines, exclusive supply is treated, in and if itself as a type of vertical restraint. 
choice but to set up its own distribution network (with the attendant costs and risks that this involves). ${ }^{25}$

Second, collusion may be facilitated when all competitors make use of exclusive contracts. ${ }^{26}$ Collusion describes a situation in which rival oligopolists explicitly or tacitly agree to align their commercial policies. Because exclusive contracts rigidify the market shares of rival suppliers, they undermine oligopolists' incentives to cheat from the collusive price through a price cut. ${ }^{27}$

Finally, single branding may harm consumer welfare when the buyer is a retailer which deals directly with the final consumer. ${ }^{28}$ In such a setting, single branding reduces consumer choice within the point of sale.

\subsection{Objective justifications and pro-competitive effects}

The economic literature is replete with articles arguing that exclusive contractual relationships have often objective justifications and pro-competitive effects. ${ }^{29}$ The Guidelines on vertical restraints take several of those findings on board. They focus, in particular, on three types of welfare-enhancing effect that may arise from exclusive contractual relationships.

First, exclusive contractual relationships can neutralise free-riding amongst rival manufacturers. A free-rider problem arises when a manufacturer finances the pre-and

25 This theory can be seen, in its strategic version, as a variation of the raising rivals' costs theory, developed by Professor Salop. On this point see V. Korah and D. O'Sullivan, Distribution Agreements under the EC Competition Rules (Oxford, Hart, 2002), p.19. See T.G. Krattenmaker and S. Salop, "Anticompetitive Exclusion: Raising Rivals' Costs to Achieve Power Over Price", 96 Yale L.J. 209 (1986)

26 See the Guidelines, supra note 14, para. 151.

27 See N. Petit, Oligopoles, collusion tacite et droit communautaire de la concurrence, Bruylant, Brussels, 2007, chapters I and IV.

28 See the Guidelines, supra note 14, para. 130.

29 See B. Klein and K. M. Murphy, "Exclusive Dealing Intensifies Competition for Distribution", (2008) 75 Antitrust L.J. 433; G. F. Mathewson and R. A. Winter, "The Competitive Effects of Vertical Agreements: Comment", (1987) 77 Am. Econ. Rev. 1057-1062, H. P. Marvel, "Exclusive Dealing", (1982) 25 J. Law Econ. 1, I. R. Segal and M.D. Whinston, "Exclusive Contracts and the Protection of Investments",(2000) 31 RAND J. Econ. 603 (2000), B. Klein and A. V. Lerner, "The Expanded Economics of Free-Riding: How Exclusive Dealing Prevents Free-Riding and Creates Undivided Loyalty", (2007) 74 Antitrust L.J. 473, D. de Meza and M. Selvaggi, "Exclusive Contracts Foster Relationship-Specific Investment”, (2008) 38 RAND J. Econ. 85. 
post sales (advertisement, promotional expenses, training of workforce, etc.) investments of its retailers. This situation generates a "positive externality" which benefits rival competitors. Those consumers that have been drawn to the relevant point of sale thanks to the supplier's promotional efforts, may eventually purchase a competing product. ${ }^{30}$ Exclusive contractual relationships, and in particular single branding, ${ }^{31}$ prevent competitors from free-riding on each others' investments and, in turn, that suppliers refuse to make investments in the first place. ${ }^{32}$

Second, in some sectors which often involve branded or positional goods/services, exclusive contractual relationships limit "certification of free-rider" issues. A manufacturer willing to introduce a new "premium" product/service indeed needs to sell primarily through retailers whose reputation is to stock only 'quality' products. If the manufacturer does not limit its sales to such premium stores, its product/service may be undervalued by customers, and its marketing strategy may be put into jeopardy. To convince 'premium' stores to sell the premium product, manufacturers may thus have recourse - at least for a certain period of time - to exclusive contractual relationships (such as exclusive supply, etc.). ${ }^{33}$

Third, exclusive contractual relationships are often said to solve "hold up" issues. ${ }^{34}$ Such issues arise when a buyer makes a "specific" investment as consideration for the performance of a vertical contract (an oil refinery builds a pipeline linking its facilities to those of a particular oil supplier). The investment is "specific", because apart from the particular contractual relationship, it has no other value. It is, as economists would say, a "sunk cost". Hostage of its own investments, the buyer endsup locked into a commercial relationship with the supplier and its product, and at the mercy of its bargaining power (the supplier may for instance engage in opportunistic

30 See P. Rey and J. Tirole, "The Logic of Vertical Restraints", (1986) 76 Am. Econ. Rev., 921.

31 A single branding clause allows a supplier to ensure that its distributor focuses its efforts on marketing its product and only its product to the exclusion of the products of other suppliers. In addition, a distributor achieves economies of scale when it distributes a single product. See J. Tirole, supra note 8, p. 185 .

32 See H. Marvel, "Exclusive Dealing" (1982) 25 Journal of Law and Economics 1.

33 Not for so long as to hinder large-scale dissemination, however. See the Guidelines, supra note 14, para. 107(c). Such benefits are more likely with "experience" or complex goods that constitute expensive purchases for the final consumer.

34 See the Guidelines, supra note 14, para. 107(d). For a discussion if the hold-up problem see O. Hart and J. Tirole, "Vertical Integration and Market Foreclosure", Brookings Paper on Econ. Activity: Microecon. 205 (1990). 
behaviour by discontinuing the supply of oil or by raising prices). To avoid the risk of moral hazard arising, the parties may enter into exclusive contractual relationships, for instance, by entering into a long-term exclusive contract, which specifies given quantities and a ceiling price. ${ }^{35}$

\section{THE RESALE PRICE MAINTENANCE GROUP}

\section{1. $\quad$ Notion of resale price maintenance}

Resale price maintenance ("RPM") arises when a supplier imposes - directly or indirectly - a resale price on its buyers. ${ }^{36}$ RPM may take the form of a fixed, minimum or maximum resale price. RPM may also arise in disguise, however, when a supplier recommends a resale price but ensures its observance through incentives (payment of premiums, discounts or other benefits in favour of its distributors) or threatens to terminate the contract, for example. A rare example of the Commission dealing with this type of restriction is provided by the $B \& W$ case. $^{37}$ In 2002 the Commission approved B\&W Loudspeakers' notified selective distribution network on condition that the company remove several hardcore restrictions, such as a disguised resale price maintenance clause stipulating minimum retailer prices and margins.

\subsection{Theories of competitive harm}

The theories of competitive harm ascribed to RPM assume that the supplier imposes the same price on all of its buyers. They borrow heavily from the economics of horizontal collusion. First, in ways similar to horizontal price collusion amongst purchasers ${ }^{38} \mathrm{RPM}$ eliminates price competition at the distribution level. ${ }^{39}$ Second,

35 There are other ways to avoid this risk, for example by pooling the investment in a joint venture. See V. Korah and D. O'Sullivan, supra note 25, p. 32.

36 A system of price-thresholds or minimum prices has the same effect.

37 See Commission Press Release, 24 June 2002, Commission clears B\&W Loudspeakers distribution system after company deletes hard-core violations, IP/02/916, Brussels.

38 The prohibition imposed on resale price maintenance is thus consistent with the primacy accorded by the Commission to the fight against horizontal collusion. The Commission - via its Guidelines - would appear to agree that resale price maintenance has detrimental consequences on competition by stating that resale price maintenance reduces or even eliminates intra-brand competition. See, for arguments in favour of a per se prohibition F. Van Doorn "Resale Price Maintenance in EC Competition Law: The Need for a Standardised Approach", 6 November 2009, available at SSRN: http://ssrn.com/abstract=1501070. 
RPM assists horizontal price collusion amongst suppliers (tacit or explicit). ${ }^{40}$ Fixing resale prices makes it easier for parties to a horizontal cartel to monitor adherence to a joint line of action. Indeed, if prices are fixed at the resale level, a reduction of market shares at the upstream level can only be explained by the deviation of a cartelist. ${ }^{41}$ Finally, RPM often entails a uniform resale price, which prevents efficient price discrimination by resellers (price discrimination leads to an increase in output and a more efficient recovery of fixed costs).

\subsection{Objective justifications and pro-competitive effects}

The works of Lester Telser ${ }^{42}$ in the 1960 s - and more generally of Chicago scholars have shed light on the objective justifications, and possible pro-competitive effects, of RPM. $^{43}$ First, RPM arguably allows suppliers to protect themselves against the risk that retailers engage in a race to the bottom in terms of prices, at the expense of quality of service. ${ }^{44}$ Second, RPM protects the image of certain branded or positional products, which would otherwise be less valued by customers (for instance, luxury goods). Third, suppliers will often use RPM to convince new operators to join a distribution network. Absent RPM, new operators are unlikely to join a distribution network for fear of facing aggressive price competition from incumbent retailers.

39 Additionally, it ought to be noted that a system of maximum or recommended prices, in which resellers remain free to choose a lower or different price, in effect acts as a focal point around which distributors can converge. See the Guidelines, supra note 14, para, 227: "The possible competition risk of maximum and recommended prices is that they will work as a focal point for the resellers and might be followed by most or all of them and/or that maximum or recommended prices may soften collusion between suppliers". In other words, the Commission sees in this a strategy based on revealing information to competing suppliers regarding the optimal price level to be reached.

40 See the Guidelines, supra note 14, para. 224. See, in particular, B. Jullien and P. Rey, "Resale Price Maintenance and Collusion" mimeo, University of Toulouse, 2002; M. Motta, Competition Policy - Theory and Practice, Cambridge University Press, Cambridge, Massachusetts, 2004. See also F. Mathewson and R. Winter, "The Law and Economics of Resale Price Maintenance", (1998) 13 Rev. Indus. Org. 57.

41 Systems of resale price maintenance increase price transparency a corollary of which is an increase in the risk of tacit collusion in concentrated markets. See the Guidelines, supra note 14, para. 224.

42 See L. Telser, "Why Should Manufacturers Want Fair Trade", (1960) 3 J. L. \& Econ. 86.

43 See on these points, H. Hovenkamp, Federal Antitrust Policy - The Law of Competition and Its Practice, 2nd Ed, West Group, St. Paul, Minnesota, 1999, paras. 11.3-11.3.c.

44 In order to make cost savings. On this point, the Chicago authors recognise that control of resale prices eliminates price competition. However, such systems do lead to competition on other equally crucial parameters. 
Fourth, when both the upstream and downstream markets are subject to a monopoly, RPM eliminates risks of "double marginalization". 45

\section{THE LIMITED DISTRIBUTION GROUP}

\subsection{Notion of limited distribution}

In a limited distribution system, a supplier restricts the number of distributors to which it sells goods or services. ${ }^{46}$ In a first variant, the supplier selects a limited number of distributors on the basis of a set of quantitative and/or qualitative conditions. ${ }^{47}$ This type of limited distribution is referred to as "selective distribution". In a second variant, the supplier decides to appoint one distributor for a given geographic area (or for a category of customer). This type of limited distribution is referred to as "exclusive distribution" (or "customer exclusivity"). ${ }^{48}$

\subsection{Theories of competitive harm}

Limited distribution systems are likely to trigger two types of restrictive effect on competition. First, limited distribution generates foreclosure concerns. Those buyers that do not belong to a limited distribution network are unable to obtain inputs from the relevant supplier. There is therefore a risk of "input foreclosure" which, depending on the market power of the manufacturer, in turn reduces intra-brand competition at the buyer level. ${ }^{49}$

45 In certain markets, where both the supplier and buyer have market power, it is possible that supracompetitive profits are made twice. In this context one normally speaks of "double marginalisation". A supplier, wishing to protect its sales profits but also avoid a reduction in quantities sold at resale level can control the profits of its distributor by fixing downstream prices. See J. Tirole, supra note 8, p. 174.

46 See the Guidelines, supra note 14, para. 174.

47 Conditions relating to personnel, premises, etc. The supplier may also impose an entry fee (for example, in franchise systems). See J. Tirole, supra note 8, p.184.

48 Exclusive supply arrangements, which were discussed above, are drastic forms of limited distribution.

49 See the Guidelines, supra note 14, para. 175. 
Second, because it is easier to coordinate amongst a small number of entities, limited distribution facilitates collusion - tacit or explicit - amongst purchasers. ${ }^{50}$ In addition, limited distribution facilitates collusion - tacit or explicit - amongst suppliers, because the monitoring of deviations becomes simpler with a limited number of retail outlets. This risk is particularly acute in cases of multiple exclusive distribution where several suppliers appoint the same distributor for the same territory.

\subsection{Objective justifications and pro-competitive effects}

Most of the objective justifications for limited distribution are predicated upon the economic theory of incentives. ${ }^{51}$ In particular, Chicago school scholars have long argued that suppliers grant contractual protection to their distributors to stimulate their incentives to invest. On markets for durable and complex goods (cars, computers, stereos, etc.), distributors often provide essential pre and post-sales services such as consulting, testing, demonstrations, explanations of the relevant documentation, etc. ${ }^{52}$ Those services come, however, at a cost, which in turn translates into higher prices. Distributors providing such services are thus vulnerable to the risk that consumers select a product within their point of sale, but subsequently purchase it from a different distributor who offers a more attractive price (precisely because it has incurred similar costs in pre and post-sales services). ${ }^{53}$

To maintain retailers' incentives to invest in pre-and post-sales services, and avoid this free-rider problem, suppliers may grant territorial protection, customer exclusivity, or enter into an exclusive supply commitment. More generally, such contractual protection is equally useful when a distributor must make an "initial investment" on a new market, ${ }^{54}$ undertake "promotional efforts", 55 or when it has a certain reputation for quality on the market. ${ }^{56}$

50 Collusion between downstream buyers is facilitated because an understanding of the terms of coordination is simpler; monitoring activities is easier; and the risk of entry is reduced.

51 See J.J. Laffont and D. Martimort, The Theory of Incentives: The Principal-Agent Model, Princeton University Press, 2001.

52 Pre-sales services are recognized in the Guidelines, supra note 14, para. 107(a).

53 See J. Tirole, supra note 8, p.183.

54 See the Guidelines, supra note 14, para. 107(b), which states "to open up or enter new markets".

55 See the Guidelines, supra note 14, para. 107(a), which mentions the "free-rider problem". Also note that the usual providers of capital (banks, equity markets) may provide capital sub-optimally when they have imperfect information on the quality of the borrower or there is an inadequate 
In addition to such "incentives" effects, limited distribution engenders a range of “costs" effects. First, limited distribution triggers economies of scale, i.e. a reduction in the average total costs of production (the typical cost of each unit produced). ${ }^{57}$ For instance, in exclusive supply relationships, the supplier only deals with one buyer. Assuming that the supplier finances (part of) a buyer's equipment, the fixed financial burden of this investment can be allocated over its entire production scale. In contrast, if the supplier has contractual dealings with several buyers, its investments in equipment would be multiplied and the fixed financial burden of each fixed investment would have to be spread over fewer quantities. As a result, its average total cost would be higher. ${ }^{58}$

Second, limited distribution reduces the number of contractual partners of the supplier, and thus limits transaction costs (delivery, billing, monitoring, negotiations, etc.). ${ }^{59}$

Finally, some types of limited distribution arrangements, and in particular selective distribution, allow suppliers to prevent "principal-agent" problems. Some retailers subject to competition may neglect quality of service ex post, and in turn harm the uniform reputation/brand image of the suppliers' good. To alleviate such concerns, suppliers may apply ex ante selection systems (selective distribution), ${ }^{60}$ or contractually require that the distributors comply with a list of specifications in terms of know-how and image they wish to convey (franchising). ${ }^{61}$

basis to secure the loan. The buyer or supplier may have better information and be able, through an exclusive relationship, to obtain extra security for its investment. Where the supplier provides the loan to the buyer, this may lead to non-compete or quantity forcing on the buyer. Where the buyer provides the loan to the supplier, this may be the reason for exclusive supply or quantity forcing vis-à-vis the supplier. See Guidelines, supra note 14, para. 107(h).

56 See Guidelines, supra note 14, para. 107(c), referring to the "certification free-rider issue".

57 See the Guidelines, supra note 14, para. 107(g).

58 See J. Tirole, supra note 8, p.193.

59 See V. Korah and D. O'Sullivan, supra note 25 , p.37, noting that such considerations were at the heart of the old laws which have since been abolished.

60 See the Guidelines, supra note 14, para. 174.

61 In this type of distribution network, it is common to prohibit the resale of goods/services to unauthorized distributors outside of the network. 


\section{THE MARKET-SHARING GROUP}

\subsection{Notion of market sharing}

Put simply, in a market sharing arrangement, a supplier restricts the venues where its buyers can purchase or sell contractual goods/services. ${ }^{62}$

A first form of market sharing is exclusive purchasing. ${ }^{63}$ Here, a buyer commits to purchase exclusively from one particular supplier (for example, from a regional wholesaler) in order to meet its requirements of a given product/service. In contrast, the buyer cannot purchase from other suppliers of the same product (other wholesalers in other geographical regions). ${ }^{64}$

A second conventional form of market sharing involves the resale side of the market, and often arises in the context of exclusive distribution systems (where each buyer is primarily responsible for the resale of the product/service on a given territory/to a designated type of customer). ${ }^{65}$ There is market sharing when a supplier restricts its distributors' freedom to resell outside the assigned territory/designated customer base. ${ }^{66}$ In this context, a distinction is usually drawn between restrictions of "active sales" (the buyer cannot actively solicit customers outside its territory) ${ }^{67}$ and

62 See the Guidelines, supra note 14, para. 168. These territorial systems are more frequent when the downstream party is a wholesaler (as opposed to a retailer).

63 See, for example, the many cases concerning exclusive supply clauses in the beer industry: Judgment of the Court of Justice of the European Union, Case C-23/67, SA Brasserie de Haecht $v$. Consorts Wilkin-Janssen, [1967] ECR 525; Judgment of the Court of Justice of the European Union, Case C-234/89, Delimitis, [1991] ECR I-935.

64 However, unlike single branding, it retains the ability to buy and sell competing products. Single branding and exclusive purchasing are usually grouped together under the concept of non-compete obligations.

65 On exclusive distribution, see supra section II. 2.

66 The supplier may also restrict its distributors' ability to resell products/services to certain types of customers (business customers or private clients, for example).

67 'Active' sales mean actively approaching individual customers by for instance direct mail, including the sending of unsolicited e-mails, or visits; or actively approaching a specific customer group or customers in a specific territory through advertisement in media, on the Internet or other promotions specifically targeted at that customer group or targeted at customers in that territory. Advertisement or promotion that is only attractive for the buyer if it (also) reaches a specific group of customers or customers in a specific territory, is considered active selling to that customer group or customers in that territory - see the Guidelines, supra note 14, para. 51. 
restrictions of "passive sales" (the buyer cannot meet unsolicited orders from customers outside its territory). ${ }^{68}$

Market sharing is polymorphous. In its purest form, a contractual clause may directly forbid the resale of products/services outside the relevant territory (or designated type of customer). Alternatively, the supplier may use indirect incentives (financial rewards or penalties) to encourage distributors to confine their deliveries to their assigned territory/customer base.

The Nintendo case provides a good illustration of unlawful market-sharing. In a 2002 decision, the Commission found that Nintendo and several of its EU distributors had colluded to artificially keep high price differentials across several Member States. ${ }^{69}$ Under the collusive arrangement, each distributor was required to prevent parallel trade from its territory to other territories (parallel trade involves exports from low price countries to high price countries). ${ }^{70}$ In practice, Nintendo and several distributors had taken active steps to stem parallel trade. Distributors that had allowed parallel exports were punished through supply reductions (or even boycott). As a result of such conduct, the Commission meted out a $€ 167.8$ million fine on Nintendo and seven of its official distributors.

\subsection{Theories of competitive harm}

In a market sharing system, each buyer enjoys a monopoly over the resale of a product/service to a particular territory/type of customer. Intra-brand competition is thus entirely eliminated. If the degree of inter-brand competition is limited, each

68 'Passive' sales mean responding to unsolicited requests from individual customers including delivery of goods or services to such customers. General advertising or promotion that reaches customers in other distributors' (exclusive) territories or customer groups but which is a reasonable way to reach customers outside those territories or customer groups, for instance to reach customers in one's own territory, are considered passive selling. General advertising or promotion is considered a reasonable way to reach such customers if it would be attractive for the buyer to undertake these investments also if they would not reach customers in other distributors' (exclusive) territories or customer groups - see the Guidelines, supra note 14, para. 51.

69 See Commission decision of 30 October 2002, Video Games, Nintendo Distribution, (2003) OJ L $255 / 33$.

70 In this case, there were striking price differences across Europe. According to the Commission, in early 1996 some Nintendo products were up to $65 \%$ cheaper in the United Kingdom than in The Netherlands and Germany. 
buyer thus enjoys "significant market power" (the ability to raise prices significantly and durably above the competitive level). ${ }^{71}$

In addition, market sharing is likely to thwart the integration of the Internal Market, when resale restrictions partition markets along national lines. In this variant, differentiated prices will prevail across Member States. This goes against the philosophy of EU market integration, which seeks to ensure homogeneous conditions for customers across the EU. ${ }^{72}$

Finally, market sharing facilitates collusion. With market sharing, a buyer's price cuts do not generate larger sales. Hence, buyers' incentives to deviate from a tacit or explicit collusive equilibrium are limited.

\subsection{Objective justifications and pro-competitive effects}

Even more clearly than exclusive distribution, market sharing eradicates free-rider issues, and may thus encourage buyers to invest in pre-and post-sales services. Importantly, such systems are often imposed by suppliers on - possibly reluctant buyers who are prone to compete aggressively on price at the expense of quality. ${ }^{73}$

\section{THE BUYER POWER GROUP}

\subsection{Notion of buyer power}

In mainstream competition economics, buyer power is traditionally seen as a disciplining factor against the market power of large suppliers. ${ }^{74}$ Strong buyers indeed have the ability and incentive to bring new sources of supply on the market in response to a small but permanent increase in relative prices. ${ }^{75}$

71 Limited by inter-brand competition, both from other goods or services.

72 See the Guidelines, supra note 14, para. 100(d).

73 Assuming that several distributors of a supplier are in a position to compete, one means of control at the supplier's disposal is to segment the market between the relevant distributors by carving up sales territories. See J. Tirole, supra note 8, p. 472.

74 See R. Inderst and G. Shaffer in "Buyer Power in Merger Control", ABA Antitrust Section Handbook, Issues in Competition Law and Policy, W.D. Collins(ed.) who define buyer power as "the ability of buyers to obtain advantageous terms of trade from their suppliers."

75 See the Guidelines, supra note 14, para. 116. 
In this context the Guidelines delve into unknown territory by turning buyer power into theories of competitive harm. The Guidelines seek in particular to offer guidance on two novel areas, namely upfront access payments (i.e., payment of fixed fees by suppliers to retailers in order to gain access to their shelf space - known as slotting allowances) and category management agreements (i.e. agreements where the distributor entrusts a given supplier - a "category captain" - with the marketing of a category of products, which include rival products).

Such issues have, however, been dealt with at Member State level. In the United Kingdom, for example, the Office of Fair Trading in the anticipated acquisition by United Biscuits (UK) Limited of the Jacobs Bakery Limited has recently grappled with the issue of category management. In this case, some competitors raised concerns about the power of the merged firm to further its own sales at the expense of those of its rivals using its control over the supermarkets through the category management process. In the context of this merger, the OFT did not, however, expect a retailer (particularly a major supermarket chain) to permit itself to be disadvantaged by its choice of category manager, or adherence to its recommendations. ${ }^{76}$

\subsection{Theories of competitive harm}

The Guidelines ascribe two theories of harm to upfront access payments. First, they may lead to anti-competitive foreclosure of (i) other distributors if such payments "induce the supplier to channel its products through only one or a limited number of distributors" and - exceptionally; ${ }^{77}$ (ii) of other suppliers where the widespread use of upfront access payments increases barriers to entry for small entrants. ${ }^{78}$ Second, the Guidelines state that, upfront access payments may reduce competition and facilitate collusion between distributors. According to the Commission upfront access

76 Such that it resulted in a failure to provide an optimum product mix, which would have maximised the overall profitability of its biscuit range. See UK OFT decision of 10 September 2004 (Anticipated acquisition by United Biscuits (UK) Limited of the Jacobs Bakery Limited) where it was also stated that category management involves a leading supplier providing expertise to the retailer to help it to maximise the profitability of each of its product ranges. This may involve providing research on the best way to market products and at what time, for example.

77 See the Guidelines, supra note 14, para 204.

78 See the Guidelines, supra note 14, para 205. 
payments are likely to increase the price charged by the supplier for the contract products since the supplier must cover the expense of those payments. In turn, and without much explanation in relation to the collusion issue, the Guidelines consider that these higher supply prices may reduce retailers' incentives to compete on price downstream, while the profits of distributors are increased as a result of access payments. $^{79}$

According to the Commission category management agreements generally do not raise competition law concerns. Yet, they may occasionally lead to the foreclosure of other suppliers "where the category captain is able to limit or disadvantage the distribution of products of competing suppliers". ${ }^{80}$ In addition, such agreements may facilitate collusion between distributors when the same supplier serves as a category captain for all or most of the competing distributors on a market. In a rather terse manner, the Guidelines state that in such cases the category captain will provide a common point of reference for the distributors' marketing decisions. ${ }^{81}$ More convincingly, the Guidelines consider that category management may also facilitate collusion between suppliers through increased opportunities to exchange sensitive market information. ${ }^{82}$

\subsection{Objective justifications and pro-competitive effects}

As far as upfront access payments are concerned, the Commission recognises that they may lead to efficiencies such as the efficient allocation of shelf space for new products. In addition, they reduce the risk of free riding by suppliers on distributors' promotional efforts. ${ }^{83}$ This is relevant in particular when suppliers are tempted to launch new products, which are suboptimal. With upfront access payments, the risk of commercial failure does not bear entirely on the buyer. In other words, upfront access

79 See the Guidelines, supra note 14, para 206. For a discussion of slotting allowances and their impact on the competitive process, see O. Foros and H.J. Kind, "Do Slotting Allowances Harm Retail Competition”, CESIFO Working Paper No. 1800, Industrial Organisation, September 2006.

80 See the Guidelines, supra note 14 , para 210.

81 See the Guidelines, supra note 14, para 211.

82 The French NCA has issued an opinion on this subject, see http://www.autoritedelaconcurrence.fr/user/avisdec.php?numero=10-A-25

83 See the Guidelines, supra note 14, para. 208. 
payments are a risk sharing mechanism, which limits the risk that suppliers will launch suboptimal products at the expense of buyers.

As far as category management agreements are concerned, the Commission considers that they may allow distributors to have access to the supplier's marketing expertise for a certain group of products. In particular, since such agreements are based on customers' habits, they lead to increased customer satisfaction by satisfying demand expectations. Put simply, they ensure that the optimal quantity of products is presented directly on the shelves in a timely manner. ${ }^{84}$ Moreover, such agreements generate costs economies for the buyer, which outsources the management of a category of products to a supplier. Finally, category management agreements generate economies of scale, as the cost of managing a category of products is merely incurred once (by the category captain), and can be spread over a wide range of products.

\section{A STEP-BY-STEP METHOD FOR THE SELF-ASSESSMENT OF VERTICAL RESTRICTIONS}

With the increased risks stemming from the enforcement of the EU competition rules (i.e., swingeing fines, annulment and damages actions, negative reputation, etc.), firms should regularly self-assess vertical agreements through the lenses of Article 101 TFEU. $^{85}$

To this end, the Guidelines on Vertical Restraints suggest that "the assessment of a vertical restraint involves in general [...] four steps", ${ }^{86}$ which requires in particular a preliminary delineation of the relevant market. ${ }^{87}$ In our opinion, this somewhat complex method can be whittled down to a simpler two-step method. First, firms and their counsels should screen their agreement against a set of compatibility and incompatibility presumptions, which can be found in the Regulation and Guidelines (1). Second, only those agreements that escape such presumptions must be subject to

84 See the Guidelines, supra note 14, para. 213.

85 For some enlightening proposals on this point see, see P. Lugaard and J. Haan, "Ten Points to Consider when Reviewing Regulation 2790/1999", Global Competition Policy Online, March 2009.

86 See the Guidelines, supra note 14, para. 110.

87 Id. "First, the undertakings involved need to establish the market shares of the supplier and the buyer on the market where they respectively sell and purchase the contract products". 
a full-blown individual competition analysis (2). For the purposes of the present paper, we only deal with vertical agreements covered by Regulation 330/2010, ${ }^{88}$ and we take it as a given that trade between Member States is affected.

\section{SCREENING OF VERTICAL RESTRAINTS}

Since 1999, the law of vertical agreements relies extensively on presumptions. ${ }^{89}$ The Regulation and the Guidelines establish two sets of presumptions, which from the outset permit one to ascertain whether or not their purported vertical agreement falls foul of the EU competition rules. Pursuant to those texts, parties to a vertical agreement must first verify whether their purported agreement falls within the presumption of incompatibility provided for in Article 4 of the Regulation (1.1). Vertical agreements which fall outside this presumption of incompatibility may in turn be presumed compatible with Article 101 TFEU, if certain conditions defined in the Regulation and the Guidelines are fulfilled (1.2). As will be seen below, only those vertical agreements that do not benefit from those presumptions are subject to a full-blown individual competition analysis.

\subsection{The presumption of incompatibility}

\subsubsection{Preliminary remarks}

88 See Article 2(1) of the Regulation, supra note 4. We therefore do not discuss agreements that fall outside the scope of the Regulation and the Guidelines i.e. (i) agreements between competing firms (with the exception of section 2(4) of the Regulation on non-reciprocal vertical agreements), (ii) agreements concluded within the framework of an association of retailers of goods (other than section 2(2) relating to relations between the association and its members), (iii) vertical agreements falling within a specific block exemption (see Article 2(5) of the Regulation), such as motor vehicle distribution agreements, (iv) agreements pertaining to leases and rental agreements (see the Guidelines, supra note , para. 26). We also exclude real agency contracts. A "real" agency contract does not fall within the purview of Article 101(1) TFEU. A "false" agency contract does on the other hand fall within the ambit of Article 101 TFEU. The dividing line between these two types of contract is drawn by reference to the criterion of imputability of financial and commercial risks associated with the contract. A real agency contract is one by which the agent bears no financial risk. Conversely, a false agency contract is a contract where the financial risk and the risks associated with the non-performance of contractual obligations is imputed to the agent. See the Guidelines, supra note 14, paras. 13-16. Article 101(1) TFEU is applicable to agency contracts when the agent assumes one or more of the following risks: the agent contributes to the costs associated with the supply of the goods or services (e.g. transport costs), the agent invests in promotional activities, the agent sets up and operates at its own expense an after-sales service or warranty system, the agent makes market-specific investments in equipment, facilities or staff training; the agent assumes liability vis-à-vis third parties for products sold, the agent assumes responsibility for the non performance of the contract by the customer etc.

89 See F. Wijckmans et al., supra note 11, para. 1.52. 
Article 4 of the Regulation sets down a list of five "hardcore restrictions", (sometimes referred to as "black clauses") whose presence in a vertical agreement ipso jure leads to (i) a presumption that the agreement as a whole restricts competition within the meaning of Article 101(1) TFEU; (ii) the exclusion of the application of the block exemption to the entire agreement; ${ }^{90}$ and (iii) a presumption that "the agreement is unlikely to fulfil the conditions of Article 101(3)". ${ }^{91}$ Such restrictions are thus subject to a quasi per se prohibition. There is therefore no need to undertake a painstaking assessment of the economic effects of the agreement. Moreover, the incompatibility rule affects the entire agreement, which is thus deemed null and void as a whole under Article 101(2) TFEU.

Interestingly, and despite Internet players' calls to that effect, ${ }^{92}$ Article 4 does not specifically target restriction(s) on buyers from selling goods/services on the Internet. In our opinion, the silence of Article 4 in relation to online sales is precautionary in nature. Absent any track-record on this issue, the Commission has seemed reluctant to cast in stone a restrictive solution, which could soon have become obsolete in sectors driven by rapid technological change. ${ }^{93}$ Rather, the Guidelines have favoured a caseby-case approach, comparable to the approach taken notably in the French case-law. ${ }^{94}$

\subsubsection{Resale price maintenance}

90 They are of such gravity that the illegality of the clause in question affects the validity of the entire agreement, even where the market-share threshold (to which we shall return) is not exceeded. See the Guidelines, supra note 14, paras. 47-59. Such restrictions are not severable from the remainder of the agreement. This is important because other restrictions deemed inconsistent with Article 101(1) TFEU (and not covered by Article 101(3) TFEU) after an individual assessment remain severable from the agreement (these restrictions are mentioned in Article 5 of the Regulation). Only such clauses are incompatible and the remainder of the agreement survives. See our comments below.

91 See the Guidelines, supra note 14, para. 47.

92 See eBay's "Empowering Consumers by Promoting Access to the 21 st Century Market, A Call for Action", p. 11.

93 See LVMH submission concerning the review of the EU competition rules applicable to vertical restraints of 24 September 2009. The luxury product industry generally considers that the growth of online sales of luxury products, the continual adoption of new technologies for Internet advertising and sales make it impossible to adopt exhaustive legislation in this context.

94 The approach taken by the French competition authority can be lauded as flexible, as it takes a case-by-case approach. See Decision of the French Conseil de la Concurrence, Decision no. 08-D25 of 29 October 2008 and the Paris Court of Appeal judgment of 29 October 2009. The Paris Court of Appeal referred to the Court of Justice a request for a preliminary ruling in the case Pierre Fabre Dermo Cosmétique S.A.S (Case C-439/09). 
The first hardcore restriction targets RPM. It declares incompatible agreements which have as their object "the restriction of the buyer's ability to determine its sales price". ${ }^{95}$ Under such agreements, the buyer must observe a fixed (or minimum) resale price, set in the contract. ${ }^{96}$ Importantly, indirect RPM mechanisms are also caught by the prohibition. ${ }^{97}$ For instance, agreements setting a minimal profit $\operatorname{margin}^{98}$ or a maximum discount level are presumed incompatible. ${ }^{99}$ In contrast, a maximum ${ }^{100}$ or recommended ${ }^{101}$ price (or price level) is not in principle a hardcore restriction, unless it disguises an indirect RPM mechanism (when linked to the exertion of pressure, penalties or incentives). ${ }^{102}$

95 Understood as the objective ability of the agreement and not the intention of the parties. See Article 4(a) of the Regulation and the Guidelines above, supra note 14, para. 48. For a discussion of RPM see O. Foros, H.J. Kind and G. Schaffer, Resale Price Maintenance and Restrictions on Dominant Firm and Industry-Wide Adoption, CESifo Working Paper Series No. 2032, 2007; see also V. Verouden, Vertical Agreements: Motivation and Impact in Issues in Competition Law and Policy (W.D. Collins, ed.), ABA Section of Antitrust Law, 2008. See also F. Alese, "Unmasking the Masquerade of Vertical Price Fixing", (2007) 28 ECLR 514 and M. Kneepkens "Resale Price Maintenance: Economics Call for a More Balanced approach", (2007) 28 ECLR 656.

96 See Judgment of the Court of Justice of the European Union, Case C-243/83, SA Binon \& Cie v. SA Agence et messageries de la presse, [1985] ECR p. 2015; Judgment of the Court of Justice of the European Union, Case 107/82, AEG/Telefunken v. Commission [1983] ECR p. 3151.

97 For an example of a clause permitting an undertaking to scrutinise the wording of dealers' advertisements as regards selling prices and to prohibit such advertisements, see Judgment of the Court of Justice, Case C-86/82, Hasselblad v. Commission [1984] ECR 883.

98 See in particular Commission decision of 16 July 2003, Yamaha, paras. 81-2 and 144, not yet published.

99 The prohibition extends to some extent to mechanisms that ensure the monitoring and detection of distributors who do not respect the set price level. The existence of such mechanism raises suspicions of a concerted practice or vertical price fixing. It may be, for example, an obligation imposed on a distributor to denounce other distributors who depart from the standard price. See also with regard to agency the special case pertaining to a prohibition on the agent to share its commission with the customer. See the Guidelines, supra note 14, para. 48, codifying the Judgment of the European Court of Justice, Case C-311/85, Vereniging van Vlaamse Reisbureaus, [1987] ECR 3801.

100 The Commission considers that the obligation to apply a maximum resale price, i.e., in this case a multiplying factor of the sales price in France by Nathan on the same products is not restrictive of competition as such. See Commission decision of 5 July 2000, Nathan Bricolux, (2001) OJ L 54/1 para. 87.

101 The General Court has drawn a distinction between mere price recommendations and the imposition of strict rules relating to retail prices: see Judgment of the General Court, Case T67/01, JCB Service v. Commission, [2004] ECR II-49. See Judgment of Court of Justice of the European Union, Case C-191/84, Pronuptia de Paris GmbH v. Pronuptia de Paris Irmgard Schillgallis, [1986] ECR 353, para. 25.

102 See the Guidelines, supra note 14 , para. 48. And more generally, threats, intimidation, sanctions, suspensions or delivery delays discouraging a buyer from deviating from a recommended price. 
Since the United States ("US") Supreme Court Leegin ruling of 2007, the tough incompatibility rule applicable to RPM has sparked intense controversy in the EU. ${ }^{103}$ In Leegin, the US Supreme Court abandoned the century old per se prohibition rule applicable to RPM, ${ }^{104}$ and subjected those practices to a rule of reason standard (which entails the balancing of the pro and anti-competitive effects of RPM). ${ }^{105}$

As a possible result of this controversy, the Guidelines have manifestly relaxed the rigidity of the incompatibility presumption enshrined in Article 4(a) of the Regulation. ${ }^{106}$ The Guidelines explicitly state that the parties have the "possibility to plead an efficiency defence under Article 101(3) in an individual case". ${ }^{107}$ The Commission thus apparently exhibits greater receptiveness to the efficiency gains arising from RPM. ${ }^{108}$

This impression is further confirmed by the text of the Guidelines, which without claiming to be exhaustive, mention three types of justification for RPM. ${ }^{109}$ First RPM may "be helpful during the introductory period of expanding demand to induce distributors to better take into account the manufacturer's interest to promote the product" by incentivising them to redouble their promotional efforts for example. ${ }^{110}$ Second, RPM may "be necessary to organise in a franchise system or similar distribution system applying a uniform distribution format a coordinated short term low price campaign (2 to 6 weeks in most cases) which will also benefit the consumers". ${ }^{111}$ Finally, the Guidelines endorse the Telserian line of justification, in

103 USC, Leegin Creative Leather Products, Inc. v. PSKS, Inc. 127 S.Ct.2705 (2007). For further discussion on this subject see W.S. Grimes, "The Path Forward after Leegin: Seeking Consensus Reform of the Antitrust Laws of Vertical Restraints" (2008) 75 Antitrust L.J. 467.

104 Which had been established in USC, Dr. Miles Medical Co. v. John D. Park \& Sons Co. 220 U.S. 373 (1911)

105 See USC, Standard Oil Co. v. United States, 221 U.S. 59-68 (1911).

106 See F. Alese and M. Kneepkens supra note 95 .

107 See the Guidelines, supra note 14, para. 223. See also para. 225 "RPM may not only restrict competition but may also, in particular where it is supplier-driven, lead to efficiencies, which will be assessed under Article 101(3)".

108 The Commission, at a roundtable discussion organized by the OECD in 2008, seemed prepared to explore all options within the framework of its review of the law pertaining to vertical restraints. The Commission indicated that the 1999 texts did not necessarily reflect its state of thinking on the issue. However, the Commission did express its doubts regarding claimed efficiencies arising out of resale price maintenance practices. OECD Competition Committee, Paris, 21-23 October 2008.

109 See the Guidelines, supra note 14, para. 225.

110 Idem.

111 Idem. 
stating that "in some situations the extra margin provided by [resale price maintenance] may allow retailers to provide (additional) pre-sales services, in particular in case of experience or complex products [sic]" and "prevent [...] free riding at the distribution level" in relation to the provision of such services. ${ }^{112}$

In theory, therefore, the parties are entitled to invoke some of the objective reasons identified by Chicago Scholars to counter a finding of incompatibility. ${ }^{113}$ That said, in practice, the flexibility introduced in the Guidelines could prove ineffectual. The majority of the efficiency benefits arising from RPM are indeed "qualitative" in nature. The various positive effects on distributors' incentives are thus not easily amenable to economic quantification, as often required under Article 101(3) TFEU. In turn, it will often prove complex to balance the harmful quantitative effects of RPM against their qualitative benefits under Article 101(3) TFEU. As a result, the balancing exercise will inevitably hinge on a value judgment - which by its nature is variable, imprecise and subjective.

\subsubsection{Territorial resale prohibitions}

a). Principle

The second hardcore restriction catches measures directly or indirectly restricting the freedom of a buyer from selling goods or services in certain geographical regions or

112 Idem. See also E. Gippini-Fournier, "Resale Price Maintenance in the EU: In Statu Quo Ante Bellum?" Fordham Corp. L. Inst - 36th Annual Conference on International Antitrust Law and Policy, 2009 (B. Hawk ed., 2010).

113 See the main justifications identified by Chicago Scholars in relation to resale price maintenance: :first, suppliers seek to protect themselves against the risk that distributors engage in a race to the bottom in terms of prices and may neglect the quality of service provided in order to make costs savings. On this point, the Chicago authors recognise that control of resale prices eliminates price competition. However, such systems do lead to competition on other equally crucial parameters. Second, suppliers sometimes seek to protect the brand image of their products (luxury goods industry, for example) from the risk that such goods are sold at rock-bottom prices. Third, suppliers impose resale prices in order to increase the density of their distribution network. Achieving density (i.e. the setting up of a significant number of points of sale) is expensive. Relevant costs are compensated by setting minimum prices which guarantees a minimum profit for distributors in the absence of which they would not distribute a given product for want of sufficiently extensive territorial coverage. Fourth, resale price maintenance is a means, for a new entrant, to persuade a distributor to market its products by offsetting the latter's investment risks. Fifth, resale price maintenance can ensure that distributors make significant profits. On these points see H. Hovenkamp, supra note 43. 
to certain customers. ${ }^{114}$ Such restrictions are akin to "market partitioning", and ought therefore to be presumed incompatible. Article 4(b) catches direct obligations not to sell to certain customers/territories, as well as obligations to dismiss orders from other customers/territories (or to refer to other distributors). ${ }^{115}$ Its scope of application also covers indirect measures which have the same effect, such as incentive schemes (conditional bonuses or discounts) and pressures (refusals to supply, threats to terminate the agreement). ${ }^{116}$ According to Article 4(b), the vertical agreement may, however, define the "place of establishment" of the buyer.

\section{b). Exceptions}

The Regulation brings four exceptions within the presumption of incompatibility. ${ }^{117}$ First, restrictions of "active sales" into a territory (or to a customer group) granted exclusively to another buyer are not presumed incompatible. A sale is "active" when the buyer solicits customers located within the exclusive territory (or customer base) assigned to another buyer. In contrast, restrictions on "passive sales" are presumed incompatible. A sale is "passive", when it originates from unsolicited orders of customers located in the exclusive territory (or belonging to the customer base) of another buyer. ${ }^{118}$ Restrictions of sales via the Internet, ${ }^{119}$ which the Commission deems to be passive and not active sales, are also presumed incompatible

Pursuant to the three other exceptions enshrined in the Regulation, a supplier can (i) restrict "sales to end users by a buyer operating at the wholesale level of trade"; (ii) prevent "members of a selective distribution system to sell to unauthorised distributors within the territory reserved by the supplier to operate that system" (iii) restrict " $a$ buyer's ability to sell components, supplied for the purposes of

114 See Article 4(b) of the Regulation, supra note 4.

115 See the Guidelines, supra note 14, para. 50. The underlying rationale of such incompatibility is that buyers must be able to sell anywhere they wish.

116 For other examples see the Guidelines, supra note 14, para. 48.

117 See Article 4(b) of the Regulation, supra note 4, and the Guidelines above, supra note 14, para. 51. These exceptions do not mean that the relevant restrictions are valid but they can, if the relevant conditions are met, qualify for an exemption.

118 See the Guidelines, supra note 14 para. 51. See also Commission Decision, Video Games, Nintendo Distribution, supra note, 69, para. 331.

119 See discussion in greater detail under section IV. 
incorporation, to customers who would use them to manufacture the same type of goods as those produced by the supplier". ${ }^{120}$

\subsubsection{Restrictions on active and passive sales in selective distribution networks}

The third hardcore restriction concerns selective distribution agreements. Pursuant to Article 4(c) of the Regulation, suppliers cannot restrict the territories/customers (in)to which selective distributors may sell to end-users. ${ }^{121}$ This presumption of incompatibility covers both active and passive sales. It thus goes further than the hardcore restriction enshrined in Article 4(b).

Contrary to a common misconception, Article 4(c) does not forbid exclusivo-selective distribution networks. Suppliers can freely select distributors, and assign to them specific territories/customers (which means that suppliers will not sell products/services to other distributors within the same territory/customer base). ${ }^{122}$ What is incompatible is to limit selective distributors' ability to make active or passive sales to end-users located within the territory of other selective distributors. Similarly, suppliers can impose a restriction on the dealer's freedom to determine the location of its business premises. ${ }^{123}$ This latter possibility permits suppliers to significantly impede the ability of pure Internet players (those without a physical infrastructure) to join a selective distribution network.

120 See the Guidelines, supra note 14, para. 55.

121 See Article 4(c) of the Regulation, supra note 4, and the Guidelines, supra note 14, para. 55.

122 See the Guidelines, supra note 14, para. 57.

123 Idem. 


\subsubsection{Restrictions of cross-deliveries in selective distribution networks}

The fourth hardcore restriction also concerns selective distribution agreements. ${ }^{124}$ Selective distributors must remain free to purchase the contract products/services from other members of the distribution network, operating either at the same or at a different level of trade. ${ }^{125}$

\subsubsection{Restrictions on component suppliers to sell to end users, repairers and independent service providers}

The last hardcore restriction covers agreements between component suppliers and buyers who incorporate them into their own products (OEM). ${ }^{126}$ OEMs may seek to reserve for themselves markets for repair and maintenance. In practice, they may restrict component suppliers' ability to sell to end users, repairers or independent service providers. ${ }^{127}$ Article 4(e) thus presumes such restrictions incompatible pursuant to Article 101(1) TFEU. The presumption of incompatibility also encompasses indirect restrictions, such as prohibitions on the component supplier to provide certain technical information to end-users. ${ }^{128}$

\subsection{The presumptions of compatibility}

Agreements devoid of hardcore restrictions may be presumed compatible with Article 101 TFEU if they fall within one of the three safe harbours established under EU competition law.

124 See Article 4(d) of the Regulation, supra note 4, and the Guidelines above, supra note 14, para. 55.

125 See the Guidelines, supra note 14, para. 58.

126 See the Guidelines, supra note 14, para. 59.

127 It may also seek to prevent mere repairs / maintenance of its product.

128 See the Guidelines, supra note 14, para. 59. The supplier may, however, impose on its own repair and maintenance network an obligation to purchase spare parts from it, and lay down a prohibition on dealing directly to the component manufacturer. 


\subsubsection{Agreements of minor importance}

a). The appreciability rule

In the Franz Völkv. SPRL Ets J. Vervaecke judgment of 1969, the ECJ held that "an agreement falls outside the prohibition when it has only an insignificant effect on the markets, taking into account the weak position which the persons concerned have on the market of the product in question". ${ }^{129}$ The Commission codified this principle the so-called "appreciability rule" or de minimis doctrine - in its Notice on agreements of minor importance of $2001 .^{130}$ Pursuant to the Notice, vertical agreements in which no party holds a market share in excess of $15 \%$ are presumed not to appreciably restrict competition within the meaning of Article 101(1) TFEU. ${ }^{131}$ This presumption of compatibility does not apply if the agreement contains a hardcore restriction. $^{132}$

b). The practice

The determination of the supplier and buyer's market shares requires a prior definition of the relevant product and geographic markets. ${ }^{133}$ The market share held by a firm indeed fluctuates with the size of the market under consideration. To take a simple example of this, Coca-Cola's market share is likely to be insignificant if one takes the view that Coca-Cola operates on the wholesale market for soft drinks. Its market share is certainly higher, however, if one takes the view that Coca-Cola operates on the wholesale market for carbonated soft drinks with a cola flavour.

Under EU competition law, the relevant product market comprises all products that consumers consider "substitutable by reason of the products' characteristics, their

129 See Judgment of the Court of Justice of the European Union, Case C 5-69, Franz Völk v. S.P.R.L. Ets J. Vervaecke [1969] ECR 295 para. 7.

130 See Commission notice on agreements of minor importance which do not appreciably restrict competition under Article 81, paragraph 1, of the Treaty establishing the European Community (de minimis), (2001) OJ C 368/13.

131 Idem. para. 7.

132 Idem. para. 11(2).

133 See the Guidelines, supra note 14, para. 88. 
prices and their intended use". ${ }^{134}$ The relevant geographic market "comprises the area in which the undertakings concerned are involved in the supply and demand of products or services, in which the conditions of competition are sufficiently homogenous". 135

In practice, an analysis of "substitutability" must be undertaken to delineate product and geographic markets. To this end, the most conventional technique consists in simulating the effect of a small, but significant and non-transitory increase in prices (5-10\%) on the demand for the product (the so-called "SSNIP test"). If demand shifts to other products and/or neighbouring geographic areas, it can readily be assumed that these products and/or neighbouring geographic areas belong to a same relevant market.

Despite its apparent simplicity, the definition of the relevant market is far from being an exact science. To take again our example above, how can one say with certainty whether Coca-Cola operates on the wholesale market for soft drinks, rather than on the wholesale market for carbonated soft drinks with a cola flavour? Of course, practitioners generally find assistance in decisional precedents, and in particular in the numerous decisions adopted by the Commission under the EU Merger Regulation. That being said, a large number of markets still remain to be defined by competition authorities. ${ }^{136}$

Moreover, the calculation of the market shares poses a significant challenge. To compute market shares, parties need data on the total sales (for the supplier) and purchases (for the buyer) achieved on the relevant market. ${ }^{137}$ In principle, however, such data is unavailable to the parties, which do not - and should not - know the

134 See Commission Notice on the definition of relevant market for the purposes of Community competition law, [1997] OJ C 372/5 para. 7.

135 Idem. para. 8.

136 And where a relevant market analysis has taken place, it may relate to a different/obsolete economic context.

137 See Article 7(a) of the Regulation, supra note 4. In the absence of reliable data on the value of sales, it is possible to rely on "estimates based on other reliable information concerning the market, including market sales volume". The market share should be calculated on the basis of data for the preceding calendar year. See Article 7(b) of the Regulation. In the case of dual distribution of final goods, i.e. where the supplier acts as an integrated distributor towards its buyers which it controls, sales to the latter are taken into account for the purposes of calculating market share. See Article 7(c) of the Regulation and the Guidelines, supra note 14, para. 95. 
amount of sales and purchases achieved by their rival (and their customers/suppliers). ${ }^{138}$

\subsubsection{Agreements between small and medium-sized enterprises (SMEs)}

The Guidelines exhibit a noticeable degree of sympathy towards SMEs (undertakings which have fewer than 250 employees, and have either an annual turnover not exceeding €40 million, or an annual balance-sheet total not exceeding €27 million). ${ }^{139}$ Vertical agreements between SMEs are deemed "rarely capable of appreciably affecting trade between Member States or of appreciably restricting competition within the meaning of Article 101(1) TFEU', and thus generally fall outside the scope of Article 101(1) TFEU. ${ }^{140}$ Should such agreements, however, satisfy the conditions for the application of Article 101(1) TFEU, "the Commission will normally refrain from opening proceedings for lack of sufficient interest for the European Union unless those undertakings collectively or individually hold a dominant position in a substantial part of the internal market". ${ }^{141}$

\subsubsection{Block exemption mechanism}

The third presumption of compatibility is the main feature of Regulation 330/2010. ${ }^{142}$ Vertical agreements which observe a dual set of market share thresholds (a), as well as a range of conditions (b) are deemed to automatically fulfil the conditions for the application of Article 101(3) TFEU. ${ }^{143}$ In some exceptional circumstances, the benefit of the block exemption may, however, be withdrawn (c).

138 See P.M. Louis, "Le nouveau règlement d'exemption par catégorie des accords de transfert de technologie: une modernisation et une simplification”,, (2004) 3-4 Cahiers de droit européen 377 , pp.385 and 403.

139 See Annex to Commission Recommendation 96/280/EC.

140 See the Guidelines, supra note 14, para. 11.

141 Idem.

142 See the Guidelines, supra note 14, para. 23, which refers to a "presumption of legality".

143 Technically, the Regulation relies on Article 101(3) TFEU to declare Article 101(1) TFEU inapplicable (Article 2 of the Regulation, supra note 4, recalls that a finding of inapplicability of Article 101(1) TFEU finds its origin in the application of Article 101(3) TFEU). The important thing to understand here is that the Regulation assumes that the conditions for exemption under Article 101(3) TFEU are met. Recital 8 of the preamble to the Regulation states that agreements that do not exceed the market-share threshold "generally lead to an improvement in production or distribution and allow consumers a fair share of the resulting benefits". 
a). The double market-share thresholds

Pursuant to Article 3 of the Regulation, a vertical agreement is presumed to benefit from the Article 101(3) TFEU exception rule:

- "[...] on condition that the market share held by the supplier does not exceed $30 \%$ of the relevant market on which it sells the contracts goods or services." and

- "the market share held by the buyer does not exceed $30 \%$ of the relevant market on which it purchases the contract goods or services". ${ }^{144}$

This "double market-share threshold" is a novelty. Interestingly, in 1999 the Commission tried to introduce a similar mechanism. The proposal attracted, however, widespread stakeholder opposition (lawyers seemed reluctant to undertake what was seen as overly complex economic assessments) and the Commission eventually opted for a single market share threshold. ${ }^{145}$. Ten years later, criticism of market share thresholds has faded. Firms and their legal counsel are often said to appreciate the legal certainty afforded by such "safe harbours". ${ }^{146}$ Despite this, however, it remains open to question whether (i) market shares are good proxy for inter-brand competition; ${ }^{147}$ and (ii) whether all firms contemplating the conclusion of a vertical

144 In the event that the market share exceeds the threshold by $5 \%$ at the end of the initial assessment of the agreement, the Regulation (Article 7) provisionally allows the exemption to remain in place. If the market share is less than $35 \%$, the agreement can benefit from the exemption for a period of two years. If the market share is greater than $35 \%$, the exemption is only valid for one year.

145 Under the legal regime in place under Regulation 2790/1999 the 30\% market share rule generally only applied to the supplier (except in cases of exclusive supply).

146 The term "safe harbour" is borrowed from the Guidelines, supra note 14, para. 23.

147 It is open to debate whether, from an economic point of view, the market-share thresholds constitute an effective screening mechanism for assessing vertical agreements. The market share thresholds are based on a structural reasoning, which borrows heavily from the teachings of the Harvard School (in particular, the SCP correlation between market share, market power and supracompetitive prices). For an illustration of such structuralism see recital 4 of the preamble to the Regulation, supra note 4, which states that an individual assessment requires that "account [be] taken of several factors, and in particular the market structure on the supply and purchase side". In a market of differentiated products (economists speak of monopolistic competition), market shares below $30 \%$ are not incompatible with the existence of significant market power. Moreover, it is open to question whether a rule based on the market shares held by the parties is really that effective for assessing the risks of oligopolistic tacit collusion. In fact, tacit collusion is a rare economic phenomenon which requires that - in addition to the presence of a tight oligopoly- 4 cumulative conditions be met: mutual understanding of the terms of coordination $(\mathrm{C} 1)$, detection of any risks of deviation (C2), the existence of a retaliatory mechanism (C3) and an absence of any challenge by forces that are exogenous to the oligopoly (C4). The issue of market share held by each party is of no particular importance. A situation of oligopolistic tacit collusion is indeed possible below the relevant thresholds. On the other hand, even in cases above the relevant thresholds it is possible that there is no risk of tacit collusion - if one of the conditions is not satisfied ( $\mathrm{C} 1$ and $\mathrm{C} 2$, for example, where the market is not transparent). One may therefore 
agreement, and in particular small ones, enjoy sufficient expertise to undertake the intricate industrial economics exercises (market definition and market share calculation) prescribed under Regulation 330/2010.

In substance, the reason behind the introduction of an additional market share threshold is predicated upon a variant of "buyer power" (or monopsony) theory. As explained previously, in mainstream competition economics, buyer power is primarily viewed as a welfare-enhancing factor, which mitigates the effects of significant market power, ${ }^{148}$ to the direct benefit of end consumers (particularly so when the buyer is a retailer). ${ }^{149}$.

However, with the vast expansion of retail distribution and the rise of gigantic players at retail level across Europe (in Belgium, France, Germany, Spain, etc.), ${ }^{150}$ concerns over the exploitation of monopsonistic buyer power have become more acute. In the context of vertical agreements, large distributors may impose on suppliers very low

question the need to carry out a complex market-share threshold assessment with regard to the risks of collusion, while the agreement could simply be screened via a check against these four conditions.

148 See, for instance, the Communication from the Commission - Guidance on the Commission's enforcement priorities in applying Article 82 of the EC Treaty to abusive exclusionary conduct by dominant undertakings (2009) OJ C 45/7, para. 18: "Competitive constraints may be exerted not only by actual or potential competitors but also by customers. Even an undertaking with a high market share may not be able to act to an appreciable extent independently of customers with sufficient bargaining strength. Such countervailing buying power may result from the customers' size or their commercial significance for the dominant undertaking, and their ability to switch quickly to competing suppliers, to promote new entry or to vertically integrate, and to credibly threaten to do so. If countervailing power is of a sufficient magnitude, it may deter or defeat an attempt by the undertaking to profitably increase prices. Buyer power may not, however, be considered a sufficiently effective constraint if it only ensures that a particular or limited segment of customers is shielded from the market power of the dominant undertaking". See also the draft Guidelines at para. 116: "In some circumstances buyer power may prevent the parties from exercising market power and thereby solve a competition problem that would otherwise have existed. This is particularly so when strong customers have the capacity and incentive to bring new sources of supply on to the market in the case of a small but permanent increase in relative prices".

149 In this sense, there has been only little, if no enforcement, of Articles 101 and 102 TFEU against monopsonistic practices. See Judgment of the Court of Justice of 15 March 2007, Case C-95/04 P, British Airways v. Commission, (2007) ECR I-2331 where there was a dominant position on a purchasing market. See also the draft Guidelines on the applicability of Article 101 of the Treaty on the Functioning of the European Union to horizontal cooperation agreements, Brussels, SEC(2010) 528/2 which devote a full section to the competitive risks associated with collective purchasing.

150 See Dobson Consulting, "Buyer Power and Its Impact on Competition in the Food Retail Distribution Sector of the European Union", prepared for the European Commission - DGIV Study Contract No. IV/98/ETD/078 who report that "the largest Belgian company, Delhaize "Le Lion", is a retailer, Britain's Tesco and J. Sainsbury both appear in the UK top 10 companies; Germany has the giant Metro group; whilst Wal-Mart Stores, number four in the US, is the eighth largest company in the world with US\$119bn turnover and 825,000 employees (Fortune, 3/8/98)". 
purchase prices, payment of listing fees or other (non) price advantages (upfront access payments). Under the previous Regulation, such agreements automatically benefited from a presumptive exemption as long as the supplier's market share did not exceed 30\%. To bring such agreements under in-depth competition law scrutiny, the new texts introduce an additional buyer's market share threshold. Only those agreements in which the buyer's market share remains below $30 \%$ are presumed to fulfil the Article 101(3) TFEU conditions. Other agreements, which possibly give rise to anticompetitive buyer power, must be subject to a full-blown, individual assessment. In other words, the new Regulation entails an extension of the substantive scope of EU competition law to new categories of agreements. This is further confirmed by the various new sections - discussed above- of the Guidelines devoted to up-front access payments and category management agreements.

That being said, the economic theory of buyer power is far from settled. ${ }^{151}$ As indicated previously, since the works of J.K. Galbraith, mainstream economic theory views buyer power as a "countervailing" factor, which leads generally to lower resale prices. In a recent study, E. Pfister asserts that "invariably, buyer power is considered a factor of competitive strength". ${ }^{152}$ In contrast, the main theories of harm associated with buyer power - albeit intuitively and theoretically valid- have not been confirmed empirically. ${ }^{153}$

Moreover, those theories of harm often seem predicated upon disputable assumptions. With respect to category management agreements, for instance, the Guidelines state that they may result in anti-competitive foreclosure of other suppliers where the category captain is able to limit or disadvantage the distribution of products of competing suppliers. ${ }^{154}$ As other commentators have noted, it is however open to question why a retailer would allow a category captain to limit competition through

151 For a discussion of buyer power see for example R. Inderst and C. Wey, "Buyer Power and Supplier Incentives" (2007), 51 European Economic Review 647; see also R. Inderst, "Leveraging buyer power", (2007) 25 International Journal of Industrial Organisation 908.

152 See E. Pfister "Puissance d'achat et politique de concurrence" Concurrences No 1-2009 1 Droit et Economie, p. 34, para. 45.

153 Idem. para. 46. To the best of our knowledge, there is no case where the Commission has grappled with the anti-competitive effects of up-front access payments and category management agreements.

154 See the Guidelines, supra note 14, para. 210. 
the foreclosure of rival upstream suppliers. ${ }^{155}$ A retailer has no interest in a limitation of upstream distribution, which will translate into increased input prices. Rather, the retailer, which strives to offer lower prices to end users, may simply use a category management scheme as an incentive device, to stimulate price competition amongst suppliers. In this setting, the retailer will appoint as the category captain the supplier which grants the largest price reductions. As long as equally efficient rival suppliers can compete for shelf management with the category captain, there is no foreclosure concern. $^{156}$

Finally, the fact that additional market shares must be calculated raises a practical, informational problem. Each party only enjoys "perfect" information on its own market share (but not on the other's). Of course, the parties can exchange information on their market shares. Yet, one cannot guarantee that the exchanged information is accurate. In this context, economic theory shows that in situations of information asymmetry, "moral hazard" issues may arise. A retailer willing to conclude - or maintain - a vertical agreement at all costs may, for example, be tempted to share incorrect information with its potential supplier. ${ }^{157}$ In such case, however, both parties, including the one which acts honestly, may be held liable for infringing Article 101(1) TFEU.

Because - from a legal policy perspective - normative standards ought to ideally be based on robust economic evidence, it would arguably have been wiser to (i) maintain the simple market share threshold of Regulation 2790/1999 for all agreements; and (ii) provide, exceptionally, that when - in certain sectors - buyer power is likely to give rise to anti-competitive effects (through the exploitation of suppliers, for instance), the Commission and National Competition Authorities ("NCAs") can withdraw the benefit of the block exemption. ${ }^{158}$

155 See P. Lugaard and T. van Dijk, "The New EC Block Exemption for Vertical Restraints: A Step Forward and a Missed Opportunity”, Global Competition Policy Online, June 2010, p.5.

156 In contrast, there may well be exploitation concerns. However, competition authorities across the EU often consider that such risks should not be dealt with as a matter of priority.

157 Besides which, the system envisaged by the Regulation leads to an increased flow of commercially sensitive information at the distribution stage insofar as the distributor must, in order to determine its market share, know how much sales are made by its competitors.

158 Under the former system, if the manufacturer held a market share below $30 \%$ - but the market share held by the distributor was above this threshold - the Commission had to use the individual withdrawal mechanism and was required to satisfy the heavy burden of proof for the application of Article 101(1) TFEU. The introduction of a $30 \%$ market share threshold in relation to 


\section{b). Conditions}

All agreements devoid of hardcore restrictions and which observe the double marketshare threshold are deemed compatible with Article 101 TFEU. ${ }^{159}$ That said, however, the parties' contractual freedom is not absolute. Article 5 of Regulation 3320/2010 identifies three types of restraint which occasionally appear in vertical agreements, and which ought to observe specific conditions. If these conditions are met, the restraint is deemed compatible, and this is the end of the self-assessment. If these conditions are not met, the restraint - and it only - cannot be deemed compatible. It must undergo a full-blown competition analysis. The rest of the agreement remains, however, covered by the presumption of compatibility. ${ }^{160}$

Article 5 first targets "direct or indirect non-compete obligations"161 (i.e. singlebranding clauses and exclusive purchasing obligations). ${ }^{162}$ It provides that the block exemption only covers non-compete obligations for a period of no more than 5 years. ${ }^{163}$ Any such obligation with an indefinite duration; of more than 5 years; or tacitly renewable beyond a period of 5 years, is excluded from the benefit of the block exemption. $^{164}$

Second, Article 5 focuses on "clauses prohibiting a buyer, after termination of the agreement, from manufacturing, purchasing, selling or reselling goods or

distributors has the effect of freeing the Commission from this burden of proof and allows it to deny the benefit of a block exemption for this type of agreement

159 In such circumstances, the parties can craft their vertical agreement as they see fit

160 The clauses in question are severable from the rest of the agreement. They themselves cannot benefit from the exemption. See the Guidelines, supra note 14, para. 71.

161 See Article 1(d) of the Regulation, supra note 4, "any direct or indirect obligation causing the buyer not to manufacture, purchase, sell or resell goods or services which compete with the contract goods or services, or any direct or indirect obligation on the buyer to purchase from the supplier or from another undertaking designated by the supplier more than $80 \%$ of the buyer's total purchases of the contracts goods or services and their substitutes on the relevant market, calculated on the basis of the value or, where such is standard industry practice, the volume of its purchases in the preceding calendar year".

162 Idem.

163 Either its duration does not exceed five years, or its renewal beyond 5 years requires the express consent of both parties.

164 The Regulation provides for a derogation from the maximum duration of 5 years when the contract goods or services are sold from premises and land which the vendor owns. As long as the buyer occupies the premises, a non-compete obligation is justified. See Article 5(2)(a) of the Regulation, supra note 4. 
services". ${ }^{165}$ Such clauses are in principle not eligible for a block exemption. ${ }^{166}$ The Regulation does, however, provide for an exception to this if the clause is: (i) indispensable to protect know-how transferred by the supplier to the buyer; (ii) limited to the retail outlet from which the buyer has operated during the contract period; and (iii) limited to one year following the expiry of the agreement. In fact, this exception primarily concerns franchising agreements, where the franchisor transfers important trade secrets to the franchisee.

Third, Article 5 excludes from the block exemption clauses which impose "any direct or indirect obligation causing the members of a selective distribution system not to sell the brands of particular competing suppliers". ${ }^{167}$ The purpose of this provision is to ensure that suppliers making use of selective distribution schemes do not foreclose access to specific competitors. In other words, the block exemption does not apply to practices which are akin to collective boycott. ${ }^{168}$ By contrast, the block exemption covers general non-compete obligations in the context of selective distribution networks.

\section{c). Withdrawal of the block exemption}

Pursuant to Article 6 of Regulation 330/2010, the Commission is empowered to declare the Regulation - and in particular the block exemption - inapplicable to "vertical agreements containing specific restraints". This exception applies only to situations "where parallel networks of similar vertical restraints cover more than 50 $\%$ of a relevant market". ${ }^{169}$ The Commission must issue a Regulation to this end. ${ }^{170}$

165 See Article 5(1)(b) of the Regulation, supra note 4 and the Guidelines, supra note 14, para. 68.

166 See the Guidelines, supra note 14, para. 60.

167 See Article 5(1)(c) of the Regulation, supra note 4, and the Guidelines, supra note 14, para. 69.

168 See the Guidelines, supra note 14, para. 69.

169 See F. Wijckmans et al., supra note 11, para. 9.08. Using the example of a market on which there are 4 competing manufacturers. Each has a market share of $25 \%$ and imposes on its respective distributors an identical single-branding clause. The cumulative effect of this network of agreements leads to the market being entirely foreclosed to new entrants. However, an assessment pursuant to the Regulation would have found the agreement valid because: (i) the relevant thresholds are respected and (ii) single branding does not as such constitute a black clause.

170 See Article 6 of the Regulation, supra note 4. The ability to do this is based on Article 7 of Regulation 17/65, which has now been replaced by Article 29(1) of Council Regulation (EC) No $1 / 2003$ of 16 December 2002 on the implementation of the rules on competition laid down in Articles 81 and 82 of the Treaty (2003) OJ L 1/1. 
In such cases, the Commission will carry out a full competition analysis of the agreement under Article 101 TFEU. ${ }^{171}$ This provision seeks to avoid so-called type II errors, which occur when a rule fails to regulate conduct that harms consumer welfare (false negatives or false acquittals).

Finally, pursuant to Article 29(1) and (2) of Regulation 1/2003, the Commission and the NCAs can respectively withdraw the benefit of a block exemption in particular cases, if an agreement has effects incompatible with Article 101(3) TFEU. ${ }^{172}$ In so far as NCAs are concerned, this is only possible if those effects "occur in the territory of that Member State, or in a part thereof, and where such territory has all the characteristics of a distinct geographic market". ${ }^{173}$

\section{FULL-BLOWN COMPETITION ANALYSIS OF VERTICAL RESTRAINTS}

\section{1. $\quad$ Preliminary remarks}

Agreements which fall short of the abovementioned screening principles must be subject to a full-blown competition analysis. ${ }^{174}$ The principles governing the individual analysis of such agreements are laid down in the Guidelines. Importantly, those principles must be applied on a case-by-case basis and not mechanically. ${ }^{175}$

\subsection{Method}

Parties undertaking a full-blown competition assessment must first identify the anticompetitive features of their agreement, and the related theories of competitive harm (2.2.1). Second, the parties must test whether those theories of competitive harm

171 See, for an illustration, Commission decision of 23 December 1992, Langnese Iglo GmbH, (1993) OJ L 183/19 and Commission decision of 23 December 1992, Schöller Lebensmittel GmbH'Co. $K G$, (1993) OJ L 183/1.

172 See paras. 13 and 14 of Regulation 330/2010, supra note 4.

173 See also Article 29(2) of Regulation 1/2003, supra note 4. See the Guidelines, supra note 14, para. 78. In this situation the Commission is also able to intervene if the case raises a particular interest such as the novelty of the relevant issues (see para. 80).

174 Those are either (i) agreements where one of the parties has a market share in excess of 30\%; or (ii) restrictions introduced into agreements which do not meet the requirements of Article 5 of the Regulation.

175 See recital 3 of the preamble to the Guidelines. 
are plausible in light of the market characteristics, and whether they are likely to give rise to a restriction of competition within the meaning of Article 101(1) TFEU (2.2.2). Third - and only if there is a restriction of competition under Article 101(1) TFEU the parties must verify if their agreement produces efficiencies and objective justifications which trigger the benefit of an exemption under Article 101(3) TFEU (2.2.3).

For the purposes of this paper, we take the illustration of a vertical agreement which contains a 3 year single branding clause, and involves a supplier controlling nearly $40 \%$ of the relevant market.

\subsubsection{Selection of the theories of harm}

Not all vertical restraints have a similar effect on competition. Economic theory ascribes specific scenarios of competitive harm to the various types of vertical restraint. A prerequisite of any meticulous self-assessment is therefore to "frame" the analysis by selecting a relevant theory of harm.

As explained previously, the Guidelines provide a useful source of guidance on this. For each group of vertical restraint, the Guidelines articulate a range of possible theories of harm. To take the example of single branding, the Guidelines particularly mention risks of (i) "foreclosure of the market to competing suppliers and potential suppliers" (customer foreclosure) ${ }^{176}$ (ii) "collusion in the case of cumulative use by competing suppliers" (supplier collusion); ${ }^{177}$ and (iii) a "loss of in-store inter-brand competition where the buyer is a retailer selling to final consumers". ${ }^{178} \mathrm{We}$ assume, here, that there is no cumulative use of single branding in the market and that the buyer is not a retailer. In such a case, none of the latter two assumptions is relevant. The individual analysis can thus focus exclusively on the risk of foreclosure.

\subsubsection{Assessment of the theories of harm}

176 See the Guidelines, supra note 14, para. 130.

177 Idem.

178 Idem. 
The next step involves testing the plausibility of the theory of competitive harm in the light of the market features. In assessing any potential risk resulting from a single branding obligation the Guidelines consider that the following list of factors should be examined: the market position of the supplier, ${ }^{179}$ the needs of individual customers covered (100\% or less), ${ }^{180}$ the market coverage of the single branding commitment (the tied market share), ${ }^{181}$ the duration of the non-compete obligation, ${ }^{182}$ the market position of competitors, ${ }^{183}$ barriers to entry, ${ }^{184}$ countervailing power (or purchasing power), ${ }^{185}$ and the level of trade. ${ }^{186}$

The Guidelines provide details on those various factors. For instance, a single branding obligation whose duration is less than 1 year is deemed unlikely to generate anticompetitive effects. In contrast, single branding obligations between 1 and 5 years entered into by non-dominant companies will usually require a proper balancing of pro- and anti-competitive effects. At any rate, single branding obligations are more likely to result in anti-competitive foreclosure when entered into by dominant companies.

The same applies to the tied market share. It is important to ascertain whether the point of sale that is foreclosed from rivals constitutes an important sales channel. If a supplier with a $40 \%$ market share benefits from a single branding commitment with a customer that accounts for $10 \%$ of its sales, the tied market share (i.e. $4 \%$ of the relevant market) is relatively limited. It is thus unlikely that the agreement restricts competition. If, however, the customer represents half of the sales of the supplier, the tied market share is much higher (i.e., $20 \%$ of the relevant market). Here, the restrictive effect of the agreement is considerably more serious.

179 See the Guidelines, supra note 14, para. 132.

180 See the Guidelines, supra note 14, para. 133.

181 Idem.

182 Idem. "Single branding obligations shorter than one year entered into by non-dominant companies are generally not considered to give rise to appreciable anti-competitive effects or net negative effects. Single branding obligations between one and five years entered into by nondominant companies usually require a proper balancing of pro- and anti- competitive effects, while single branding obligations exceeding five years are for most types of investments not considered necessary to achieve the claimed efficiencies or the efficiencies are not sufficient to outweigh their foreclosure effect" - see para. 133.

183 See the Guidelines, supra note 14, para. 134.

184 See the Guidelines, supra note 14, para. 136.

185 See the Guidelines, supra note 14, para. 137.

186 See the Guidelines, supra note 14, para. 138. 
In relation to the countervailing power of buyers, the Guidelines recognize that "powerful buyers will not easily allow themselves to be cut off from the supply of competing goods or services". ${ }^{187}$ Buyers may for instance request financial compensation, through lower purchasing prices. In such cases, the Guidelines do not discard competition concerns. Rather, they stress that whilst this may be beneficial to certain individual buyers, it "would be wrong to conclude automatically from this that all single branding obligations, taken together, are overall beneficial for customers on that market and for the final consumers". ${ }^{188}$

Finally, in relation to the level of trade, the Guidelines draw a dividing line between agreements concerning final products, where foreclosure is in general more likely "given the significant entry barriers for most manufacturers to start retail outlets just for their own products". ${ }^{189}$ In contrast, if the agreement concerns the supply of a final product at the wholesale level, the Guidelines are more optimistic. They consider that there is "no real risk of anticompetitive foreclosure if competing manufacturers can easily establish their own wholesaling operation". 190

\subsubsection{Efficiencies and objective justifications}

Once a vertical agreement is found to create actual or likely anticompetitive effects, the issue of an individual exemption under Article 101(3) TFEU arises. ${ }^{191}$ As explained above, vertical restraints have a number of objective justifications and produce redeeming efficiencies. For each group of vertical restraint, the Guidelines provide clarifications on admissible objective justifications and pro-competitive efficiencies.

187 See the Guidelines, supra note 14, para. 137.

188 Idem.

189 See the Guidelines, supra note 14, para. 140

190 See the Guidelines, supra note 14, para. 139. This will in turn depend on the type of product.

191 On condition that that the supplier does not occupy a dominant position. See the Guidelines, supra note 14, para. 127. 
As far as single branding is concerned, the Guidelines recognize that the supplier may seek (i) protection from free-riding by other suppliers (e.g. on promotional efforts); ${ }^{192}$ (ii) protection of a relation-specific investment made by the supplier (e.g. in equipment which can be used only to produce components for a particular buyer); ${ }^{193}$ (iii) protection from hold-up problems that may arise with the transfer of substantial know-how (which cannot be taken back by the supplier); ${ }^{194}$ (iv) to overcome capital market imperfections (e.g. it is more efficient for the supplier to provide a loan than it is for a bank). ${ }^{195}$ Interestingly, the Guidelines also declare that quantity forcing is as equally efficient as single branding, but generates less restrictive effects on competition. ${ }^{196}$

With only very few exceptions, the Guidelines provide scant guidance on the level of sophistication required in the assessment of objective justifications and efficiency benefits. ${ }^{197}$ In this regard, parties should thus seek guidance from the Commission's Guidelines on the application of Article 101(3) of the Treaty (the "General Guidelines").

In practice, parties should proceed with caution. Competition authorities are often conservative when it comes to weighing efficiency arguments. To be fair, their scepticism is understandable. Most objective justifications for vertical restraints indeed hinge on behavioural speculations (incentives of buyers), rather than on structural efficiencies (quantitative costs savings). Such justifications are thus inevitably tainted with value judgment. To take a simple example, a supplier imposing a single branding obligation may simply, but legitimately, over-estimate the risk of parasitism. Hence, it is imperative that firms conduct an objective and rigorous

192 See the Guidelines, supra note 14, para. 144. It is of course understandable that a supplier who has funded significant promotional efforts may seek to defend itself against parasitic competitors. In this context, the appropriate vertical restraint will be (i) of the non-compete type or quantityforcing type when the investment is made by the supplier; and (ii) of the exclusive distribution, exclusive customer allocation or exclusive supply type when the investment is made by the buyer.

193 See the Guidelines, supra note 14, para. 146. In the same vein, in the case of client-specific investments where, for example, an investment made by the supplier - after termination of the agreement - cannot be used by the supplier to supply other customers and can only be sold at a significant loss, a single branding obligation covering the amortization period of the investment is likely to meet the conditions of Article 101(3) TFEU.

194 See the Guidelines, supra note 14, para. 148.

195 See the Guidelines, supra note 14, para. 147.

196 See the Guidelines, supra note 14, para. 145.

197 The Guidelines nonetheless provide two examples of self assessment for non compete obligations and quantity forcing. 
assessment of the possible efficiencies of their vertical agreements. In addition, firms should keep all supportive evidence of any efficiency benefits (should subsequent administrative or judicial proceedings be launched).

\section{ONLINE DISTRIBUTION}

\section{THE CONTEXT}

Up until the adoption of the new EU framework on vertical restraints, the issue of online distribution triggered intense debate. ${ }^{198}$ In essence, pure Internet players (e.g. firms like eBay), ${ }^{199}$ argued that under Regulation 2970/1990 firms operating selective distribution networks had been free to undermine online distribution, through various types of vertical restraint. ${ }^{200}$ For instance, it was reported that suppliers operating selective distribution systems had occasionally prohibited the setting up of a website, subordinated online sales to the observance of a recommended price, placed a cap on quantities sold through the Internet, etc. ${ }^{201}$ In a document entitled "Empowering Consumers by Promoting Access to the 21st Century Market, A Call for Action", eBay thus proposed to eradicate such restraints through a new hardcore restriction, whose proposed wording would read as follows:

198 The debate on this issue started relatively early - even before the formal review process of Regulation 2790/1999 began - when the Competition Commissioner set up in 2008 a roundtable charged with discussing the future of online commerce. The work of the roundtable centred on the question of distribution via the Internet of audiovisual content protected by intellectual property rights (the iTunes case showed that European consumers could not be freely supplied throughout the EU for copyright reasons). However, the roundtable also intended to discuss the online commerce of goods/services which are not protected by such rights. Following the publication of an "Issues paper" containing a list of questions for interested parties, operators active in the sector -whether Internet or physical operators- gave their contribution to the public debate. The majority of the contributions submitted tackled the issue of a possible review of the legal framework laid down by Regulation 2790/1999 and the Guidelines. These comments gave impetus to the debate on the issue of vertical restraints and distribution via the Internet. In the footnotes that follow some of the contributions made by relevant stakeholders during the reform process are alluded to.

199 Others players in this context are www.rueducommerce.fr, Interactive Software Federation of Europe, Amazon, etc.

200 According to eBay, supra note 92, selective distribution networks could be used in an anticompetitive manner in order to render on line distribution economically unattractive, for example.

201 See K. Mahlstein, "Vertical Restraints and Competition Policy - Internet Sales, a New Dimension to be Considered", Global Competition Policy Online, March 2009; S. Kinsella and H. Melin, "Who's Afraid of the Internet? Time to Put Consumer Interests at the Heart of Competition", Global Competition Policy Online, March 2009. 
"The exemption provided for in Article 2 shall not apply to vertical agreements which, directly or indirectly, in isolation or in combination with other factors under the control of the parties, have as their object: $[\ldots](f)$ the restriction of the ability of the buyer or any of his customers to sell the contract goods or services on the Internet without prejudice to the exceptions permitted under paragraph $b . "$

Unsurprisingly, those proposals were fiercely challenged by suppliers of branded products (cosmetics, luxury goods, jewelry, watches, etc.) which rely primarily on "brick and mortar" shops for the distribution of their products. They argued in particular that pre-and post sales services (advice, testing, etc.) on the spot represent significant investments at both supplier and buyer levels. Members of such networks may in turn be reluctant to incur them, absent protection from Internet distributors. ${ }^{202}$ This would have been all the more problematic given the contribution of such services to demand growth. ${ }^{203}$

Interestingly, suppliers of branded products viewed the existing regulatory framework as satisfactory. ${ }^{204}$ They argued that the upcoming regulatory framework should confirm that selective distribution entails the freedom to condition online sales upon the existence of a physical outlet (and other qualitative requirements related, for instance, to download rates, payment interfaces, search tools, etc.). ${ }^{205}$ In reality, suppliers operating a selective network seemed favourable to cumulative distribution (physical+online). Their primary cause of concern related to pure Internet distribution, which involves players without a physical presence.

The debate over the new regulatory framework also concerned other notions, such as the concept of passive and active sales in exclusive distribution networks. According to the existing framework, Internet sales were generally deemed passive sales, which suppliers could not restrict. Yet, in light of technological progress, a number of suppliers argued that Internet sales could no longer be regarded as passive, in

202 See on this the contribution made by the Federation of the Swiss Watch Industry, pp.1-2.

203 See the LVMH contribution, pp. 38 and 40. This is in particular true for a "touch and feel" product (cosmetics, etc.), which customers necessarily test in a brick and mortar shop prior to purchasing it.

204 According to Estée Lauder in its contribution, the legal framework authorized the exclusion of 'pure players' from selective distribution networks.

205 See the LVMH contribution. This solution draws inspiration from French competition law, where the supplier can require from its physical distributors that wish to make online sales that they (i) already have a physical infrastructure in place which meets relevant qualitative criteria (ii) make the necessary investments in the site so that it has the requisite level of prestige as required within the network etc. 
particular when they entail website targeted at specific customers, customer tracking, etc. $^{206}$ Those suppliers thus argued that amendments to the regulatory framework ought to be introduced, so as to entitle suppliers to restrict certain Internet sales. ${ }^{207}$

\section{THE NEW FRAMEWORK FOR ONLINE DISTRIBUTION}

Remarkably, the new Regulation does not devote a single line to the issue of online distribution (as was the case with Regulation 2790/99). The issue is entirely left to the Guidelines which take a very favourable stance vis-a-vis online distribution. ${ }^{208}$ Paragraph 52 of the Guidelines unambiguously declares that "the internet is a powerful tool to reach a greater number and variety of customers than by more traditional sales methods, which explains why certain restrictions on the use of the internet are dealt with as (re)sales restrictions. In principle, every distributor must be allowed to use the internet to sell products [...]". This sympathetic stance has direct consequences on the rules governing selective distribution (2.1.) and on the notions of active and passive sales (2.2.).

\subsection{Selective distribution and online commerce}

In full conformity with Article 4(c) of the Regulation, the Guidelines declare that within a selective distribution system, dealers should be free to sell, both actively and passively, to all end users, also with the help of the Internet. ${ }^{209}$ That said, the Guidelines also provide suppliers with some degree of control over Internet sales. Just as they may require quality standards for brick and mortar shops, suppliers may require quality standards for the use of Internet websites. ${ }^{210}$ Drawing inspiration from

206 Chanel in its contribution considers that sales via the Internet should not be considered passive sales but active sales. See also the contribution made by the Premier League which challenges the relevance of the distinction between active and passive sales in the field of Internet distribution.

207 In contrast see the contribution made by Which. This consumer organisation considers that there have been little cross border Internet sales to the detriment of consumers. See also the position of other players, such as Swatch, which considers that the existing distinction between passive and active is appropriate on the other hand.

208 This would appear to make sense as the Commission cannot rely on any solid decisional practice in this context. There is in fact no European case law or decisional practice on the issue of the prohibition of online sales.

209 See the Guidelines para. 56.

210 Or for selling by catalogue or for advertising and promotion in general. See the Guidelines para. 54. 
the solutions promoted by the French NCA and the Paris Court of Appeals, ${ }^{211}$ the Guidelines even acknowledge that a supplier may require its distributors to have one (or more) brick and mortar shop(s) as a condition for joining the distribution system. In the same vein, a supplier may request distributors that use third party platforms to sell their products, to display the logo and brands of the contractual product on the website. ${ }^{212}$

The Commission also considers as a "hardcore restriction" any obligation which dissuades dealers from using the Internet to reach a greater number (or variety) of customers by imposing criteria for online sales which are not equivalent to those imposed for sales in a brick and mortar shop. ${ }^{213}$ Importantly, this does not mean that the criteria for online and offline sales should be uniform. ${ }^{214}$ For example, in order to prevent sales to unauthorised dealers, a supplier may place a limit on the quantities sold by its selected dealers to an individual end-user. In such cases, the cap placed on sold quantities may have to be stricter for online sales, if it is easier for unauthorised dealers to obtain products through the Internet. ${ }^{215}$

\subsection{Active and passive sales}

\subsubsection{Internet sales are passive}

The Guidelines seek to provide guidance on what constitutes a passive and active sale in the online world. As explained previously, the concept of active and passive sales is primarily relevant in relation to exclusive distribution. Suppliers can restrict a distributor's freedom to actively sell products in a territory that has been granted to a different distributor. However, unsolicited, passive sales cannot be restricted.

In principle, the setting up of a website to sell a product is viewed as a passive sale, since it is deemed a reasonable way to allow customers to reach the distributor. ${ }^{216}$ Surely, the use of a website may have effects beyond the distributor's own territory

211 See supra note 94.

212 See the Guidelines, supra note 14, para. 54.

213 See the Guidelines, supra note 14, para. 56.

214 In practice, this restriction is likely to give rise to significant interpretation problems.

215 See the Guidelines, supra note 14, para. 56.

216 See the Guidelines, supra note 14, para. 52. 
(or customer group). However, this stems from the technology itself, which allows easy access from everywhere.

The Guidelines provide illustrations of passive online sales. If a customer visits the web site of a distributor and contacts the distributor and if such contact leads to a sale, including delivery, then that sale is considered passive. The same holds true if a customer opts to be kept (automatically) informed by the distributor and this leads to a sale. Finally, the fact that a distributor offers different language options on its website (including languages not used in its territory) does not, of itself, alter the passive nature of the sale. ${ }^{217}$

Given, therefore, that the Guidelines consider Internet sales to be passive sales, sales via the Internet to another territory (or customer base) cannot be restricted on pain of falling within the presumption of incompatibility set out in Article 4 of the Regulation. In this context, the Guidelines provide four specific examples of hardcore restrictions of passive Internet selling: (i) agreements according to which an (exclusive distributor) is required to prevent customers located in another exclusive territory from viewing its website or to automatically re-route its customers to the manufacturer's or other (exclusive) distributors' websites; ${ }^{218}$ (ii) agreements whereby an (exclusive) distributor is required to terminate an Internet transaction if the credit card details reveal an address that is not within his exclusive territory; ${ }^{219}$ (iii) agreements which require that the distributor limit its proportion of overall sales made over the internet; ${ }^{220}$ and (iv) agreements whereby the buyer pays a higher price for products intended to be resold online (“dual pricing"). ${ }^{221}$

217 See the Guidelines, supra note 14, para. 51

218 See the Guidelines para. 52(a).

219 See the Guidelines para. 52(b).

220 See the Guidelines para. 52(c). However, a supplier may - without limiting the online sales of the distributor - require that the buyer sell at least a certain absolute amount (in value or volume) of the products offline to ensure an efficient operation of its brick and mortar shop.

221 See the Guidelines para. 52(d) and 64. This does not exclude the situation whereby the supplier agrees with the buyer a fixed fee (that is, not a variable fee where the sum increases with the realised offline turnover as this would amount indirectly to dual pricing) to support the latter's offline or online sales efforts. With regard to this latter restriction the Commission does consider, however, that in some specific circumstances such an agreement may fulfil the conditions of Article 101(3). Such circumstances may be present where a manufacturer agrees such dual pricing with its distributors, because selling online leads to substantially higher costs for the manufacturer than offline sales. In this regard the Commission provides an instructive example of a situation in which this may be the case: where offline sales include home installation by the distributor but online sales do not, the latter may lead to more customer complaints and warranty claims for the 
2.2.2. In exceptional circumstances, Internet sales may be considered active

The Guidelines merely lay down a presumption that Internet sales are passive. In exceptional cases, Internet sales may be considered active, and can thus be restricted. This is the case, for instance, if a distributor sends emails to consumers located in the exclusive territory of another distributor. Similarly, the Guidelines consider online advertisement specifically addressed to certain customers as a form of active selling to those customers. ${ }^{222}$ For instance, territory-based banners on third party websites are active sales into the territory where these banners are shown. ${ }^{223}$ Similarly, paying a search engine (or an online advertisement provider) to have advertisements displayed specifically to users in a particular territory is active selling into that territory.

\section{CONCLUSION}

The present paper has attempted to shed some light on the new EU competition rules governing vertical restraints. Whilst the recently adopted regulatory framework provides some useful guidance on Internet distribution, it remains - to say the least optimistic as regards the ability of firms to juggle with complex economic operations, such as market definition and market share computation. In addition, it paints a bleak picture of buyer power, which (i) marks a departure from conventional antitrust economics; and (ii) relies on fragile and untested assumptions. Practice will tell whether those extensions of the EU rules on vertical restraints are to be welcomed.

manufacturer. See also in this context the judgment handed down by the Rechtbank Zutphen, judgment of 8 August 2007, 79005 / HA ZA 06-716. The Dutch court held that a dual pricing scheme pursuant to which a supplier of built-in kitchen equipment offered less attractive pricing conditions to online distributors did not infringe Dutch or EU competition laws.

222 See Guidelines, supra note 14, para 53.

223 In general, efforts to be found specifically in a certain territory or by a certain customer group is active selling into that territory or to that customer group. 